\title{
ENOX2 NADH Oxidase: A BCR-ABL1-dependent cell surface and secreted redox protein in chronic myeloid leukemia (CML)
}

Seda Baykal-Köse ${ }^{1, \# a}$, Maud Voldoire ${ }^{2}$, Christophe Desterke ${ }^{3}$, Nathalie Sorel ${ }^{4}$, Emilie Cayssials ${ }^{5}$, Hyacinthe Johnson-Ansah ${ }^{6}$, Agnes Guerci-Bresler ${ }^{7}$, Annelise Bennaceur-Griscelli 1,3,8,9,10, Jean-Claude Chomel ${ }^{1,4}$ and Ali G Turhan ${ }^{1,3,8,9,10, *}$

${ }^{1}$ INSERM UA9, Villejuif, France

${ }^{2}$ Service de Médecine Onco-Hématologie, $\mathrm{CH}$ de la Roche-sur-Yon, la Roche-sur-Yon, France

${ }^{3}$ Université Paris Saclay, Faculté de Médecine, Le Kremlin-Bicêtre, France

${ }^{4}$ Service de Cancérologie Biologique, CHU de Poitiers, Poitiers, France

${ }^{5}$ Service d'Oncologie Hématologique et Thérapie Cellulaire, CHU de Poitiers, Poitiers, France

${ }^{6}$ Service d'Hématologie Clinique, CHU de Caen, Caen, France

${ }^{7}$ Service d'Hématologie Clinique, CHU Brabois, Vandoeuvre les Nancy, France

${ }^{8}$ INGESTEM-ESTeam Paris Sud, Villejuif, France

${ }^{9}$ Service d'Onco-Hématologie, Hôpital Paul Brousse, AP-HP Université Paris Saclay, Villejuif, France

${ }^{10}$ Service d'Hématologie, Hôpital Bicêtre, AP-HP Université Paris Saclay, Le Kremlin-Bicêtre, France

${ }^{\# a}$ Current Address: Department of Medical Biology and Genetics, Faculty of Medicine, Dokuz Eylul University, Izmir, Turkey

* Corresponding author

E-mail: turviv33@gmail.com; (A.G.T.) 


\section{Abstract}

Chronic myeloid leukemia (CML) is a myeloproliferative neoplasm caused by the acquisition of $B C R-A B L 1$ fusion in a hematopoietic stem cell. We identified the ENOX2 gene as up-regulated in $B C R-A B L 1$-expressing UT-7 cell lines through a transcriptome assay. The oncofoetal ENOX2 protein (Ecto-Nicotinamide Adenine Dinucleotide Oxidase Disulfide Thiol Exchanger 2) is expressed on the external plasma membrane surface of cancer cells and can be released in cancer patients' serum. Considering these data, we studied ENOX2 expression in CML cell lines and patients using quantitative RT-PCR, western-blots, the ELISA method, and transcriptomic dataset reanalysis. We confirmed increased ENOX2 mRNA expression in the $B C R-A B L 1$-expressing UT-7 cell line. Comparable results were obtained in CML patients at diagnosis. Western-blot analyses on UT-7 and TET-inducible Ba/F3 cell lines established the upregulation of ENOX2 protein. BCR-ABL1 has been found to induce ENOX2 overexpression in a kinase-dependent manner. In a series of 41 patients with CML, ELISA assays showed a highly significant increase of ENOX2 protein levels in the plasma of patients with CML $(p<0.0001)$ as compared to controls $(\mathrm{n}=28)$. Transcriptomic dataset (GSE4170) reanalyzes have shown specific ENOX2 mRNA overexpression in the chronic phase of the disease. Bioinformatic analyses identified several genes whose mRNA expression was positively correlated to ENOX2. Some of them encode proteins involved in cellular functions compatible with the growth deregulation observed in CML. All in all, our results demonstrate for the first time the upregulation of a secreted Redox protein in a BCR-ABL1-dependent manner in CML. Our data suggest that ENOX2 (through its transcriptional program) plays a significant role in the BCR-ABL1 leukemogenesis. Further studies are required to clarify the relationship between BCR-ABL1 and ENOX2. 


\section{Introduction}

Chronic myeloid leukemia (CML) is a myeloproliferative neoplasm characterized by the $B C R-A B L 1$ molecular rearrangement resulting from $\mathrm{t}(9 ; 22)(\mathrm{q} 34 ; \mathrm{q} 11)$ translocation. The natural history of the disease has been radically modified by tyrosine kinase inhibitors (TKIs) of first(Imatinib), second- (Dasatinib, Nilotinib, Bosutinib), and third-generation (Ponatinib). Nowadays, the life expectancy of patients diagnosed in chronic phase-CML (CP-CML) and responding to TKI therapy is very similar to that of the general population [1,2]. In most cases, the current management of CP-CML patients prevents a progression to accelerated phase or blast crisis [3]. Among hematological malignancies, CML provides a unique biological model to apprehend leukemogenesis, genetic instability, targeted therapy management, drug resistance, or stem cell persistence [4]. The constitutively active BCR-ABL1 tyrosine kinase oncoprotein is directly responsible for the oncogenic process. It initiates uncontrolled granulocyte proliferation, decreased adhesion to bone marrow niche cells, apoptosis inhibition, and increased genetic instability. Most of the aberrant signaling pathways downstream BCR-ABL1 (particularly well-known MAPK, PI3K, MYC, STAT pathways) have been known for a long time [5].

Using the human GM-CSF-dependent erythro/megakaryoblastic UT-7 cell line, our group previously uncovered novel non-conventional actors downstream to the BCR-ABL1 signaling [68]. In the present work, we highlight ENOX2 (Ecto-Nicotinamide Adenine Dinucleotide Oxidase Disulfide Thiol Exchanger 2) as up-regulated in $B C R-A B L 1$-positive cell lines. ENOX2, also named APK1 antigen, COVA1 (Cytosolic Ovarian Carcinoma Antigen 1), or tNOX (TumorAssociated Nicotinamide Adenine Dinucleotide Oxidase), is a growth-related cell surface protein. ENOX2 dimers combine two main enzymatic oscillatory activities (hydroquinone NADH oxidase and protein disulfide-thiol oxidoreductase) that alternate with a period length of approximately 22 minutes, generating an ultradian cellular biological clock of 22 hours (S1 Fig) [9-11].

Increased ENOX2 mRNA expression was also found in primary cells from CP-CML patients at diagnosis. Based on western-blot experiments carried out on UT-7 and inducible Ba/F3 cell lines, we confirmed ENOX2 up-regulation at the protein level, and we demonstrated that this phenomenon was linked to the BCR-ABL1 tyrosine kinase activity. In addition, a significant increase of ENOX2 protein levels was observed in the plasma of patients at the time of diagnosis. Reanalyzing a publicly available database, we found that ENOX2 mRNA expression was characteristic of the chronic phase of CML. Moreover, several genes' mRNA expression was shown to be positively correlated with ENOX2. Some of these genes encode proteins involved in cellular functions compatible with the dysregulated hematopoiesis observed in CP-CML. 


\section{Materials and Methods}

\section{UT-7 and TET-inducible Ba/F3 cell lines}

UT-7 cell lines were used for microarray experiments and western-blot analyses. The human hematopoietic (erythroid/megakaryoblastic) UT-7 parental cell line (UT-7/p) has been kindly provided to our lab by Dr Komatsu [12]. Its counterparts transduced with either native BCRABL1-p210 (UT-7/11 cells) or T315I-mutated-BCR-ABL1 (UT-7/T315I) resistant to first- and second-generation TKI and previously described and characterized by our group $[13,14]$. Doxycyclin-inducible BaF/p210 sin1.55 cell line has previously been described [15]. In this TETOFF model, the addition of doxycycline in the cell culture medium turns off BCR-ABL1 expression.

\section{Patients and healthy donors}

For ENOX2 mRNA expression analysis, $36 \mathrm{CP}-\mathrm{CML}$ patients at diagnosis were tested (12 females and 24 males; median age 58.6 years, range 21.5-84.8). Median follow-up was 11.3 years (range 1.8-17.4). TKI discontinuation was initiated in 15 patients in deep molecular response after a median period of 5.7 years of treatment (S1 Table). Seven of them remained in DMR after a median of 6.4 years of treatment (range 5.3-10.4). A cohort of 27 healthy donors was used as controls. Concerning the quantification of ENOX2 protein in plasma samples, independent cohorts of $41 \mathrm{CML}$ patients at diagnosis and 28 healthy controls were analyzed. This non-clinical study has been approved by the INSERM 935 Ethics committee (11 February 2014). All patients and healthy donors gave their informed consent in accordance with the Declaration of Helsinki.

\section{Transcriptome experiments}

Transcriptome experiments were performed using UT-7/11 cells expressing BCR-ABL1 as compared to parental UT-7 cells. Total RNA (in triplicate) was extracted from UT-7 cells (expressing or not BCR-ABL1) after culture. RNA quantification was performed on Nanodrop (Thermo Fisher Scientific, Santa-Clara, CA), and sample quality was evaluated on the Bioanalyzer-2100 (Agilent Technologies, Santa Clara, CA). Transcriptome analysis was performed on the Affymetrix technologies platform (Affymetrix, Santa-Clara, CA). The results from triplicate samples of each experimental group were normalized with the RMA algorithm (Affymetrix). 


\section{Quantitative RT-PCR assays}

Total RNA from whole blood of CML patients at diagnosis and healthy donors was reverse transcribed using High Capacity cDNA Reverse Transcription Kit (Life Technologies, Foster City, CA), and qRT-PCR experiments were performed using 7900 Sequence Detection System (Life Technologies). TaqMan pre-developed assays reagent (Life Technologies) were used to quantify ENOX2 (Hs00197268_m1) and B2M (beta-2 microglobulin, Hs00187842_m1) mRNA transcripts. This housekeeping gene was used as an internal reference. Theoretically, Hs00197268_m1 TaqMan expression assay allows detection of all ENOX2 mRNA splicing variants since the primers encompass exon 10 and 11 of the transcript variant 2 (NM_182314), taken as a reference (S2 and S3 Figs). Indeed, ENOX2 proteins could be the consequence of specific splicing variants promoting alternative downstream translation initiation sites [16]. Only ENOX2 mRNA resulting from exon 7 skipping (also named exon 4 minus variant in another nomenclature) appears to be translated in a functional protein that localizes to the plasma membrane's outer face of cancer cells. To quantify ENOX2 mRNA, PCR reactions were prepared in duplicates in a final volume of $25 \mu \mathrm{L}$ using the TaqMan Universal PCR Master Mix (Life Technologies). The $\% E N O X 2 / B 2 M$ was established using the $\Delta \mathrm{Ct}$ method.

\section{Western blotting}

Cells were lysed in ice with RIPA buffer $(\mathrm{NaCl} 200 \mathrm{mM}$, Tris $\mathrm{pH}=850 \mathrm{mM}$, Nonidet P40 1\%, deoxycholic acid $0.5 \%$, SDS $0.05 \%$, EDTA $2 \mathrm{mM}$ ) supplemented with $100 \mu \mathrm{M}$ phenylmethylsulfonyl fluoride, $1 \mathrm{mM}$ sodium fluoride, $1 \mathrm{mM}$ sodium orthovanadate (SigmaAldrich, St. Louis, MO). Protein separation was performed by electrophoresis on $8 \%$ polyacrylamide gel under denaturing conditions. Proteins were then transferred on PVDF membrane pre-activated in methanol. After saturation with TBS-Tween-BSA for 1 hour, membranes were hybridized with primary and HRP coupled secondary antibodies (New England Biolabs, Ipswich, MA). Membranes were revealed by chemiluminescence with SuperSignal West Dura or Femto reagents and data acquired using the G-BOX-iChemi Chemiluminescence Image Capture system (Syngene, Frederick, MD). The ENOX2 antibody used for these experiments was purchased from LSBio (LS - C346209, LifeSpan BioSciences Inc. Biotechnology. Seattle, WA). The ABL1 antibody, for the detection of translocated and non-translocated ABL1 protein, was obtained from Santa Cruz Biotechnology (Santa Cruz, CA), and beta-ACTIN (Sigma-Aldrich) was run as a control. All antibodies were used at the dilution recommended by the manufacturer. 


\section{ENOX2 protein concentration in blood plasma}

ENOX2 proteins can be shed into extracellular fluids, in which they can be detected [17]. In this study, ENOX2 protein quantitation in blood plasma was performed using the human ectoNOX disulfide-thiol exchanger 2 ELISA Kit (MBS 943476, MyBioSource Inc, San Diego, CA) according to the manufacturer's guidelines.

\section{Transcriptome dataset GSE4170}

Using DNA microarray, Radich et al aimed to compare gene expression between chronic ( $<10 \%$ blasts), accelerated (10-30\% blasts), and blast phase ( $>30 \%$ blasts) by analyzing 91 cases of CML using normal immature CD34+ cells as a reference [18]. Rosetta/Merck Human 25k v2.2.1 data matrix of normalized log-ratios from GSE4170 was downloaded on the Gene Expression Omnibus (GEO) website and annotated with the annotation platform GPL2029 to be reanalyzed, focusing on ENOX2 mRNA expression.

\section{Bioinformatics microarray data analysis}

Differentially expressed genes between the three phases of CML (GEO dataset GSE4170) were determined by Pavlidis template matching algorithm with a positive R correlation coefficient greater than 0.80 and p-value threshold less than 1E-6 [19]. Heatmap and parallel coordinate plot were carried out with the made4 R package [20] and the GGally R-package. The expression profile correlated to ENOX2 in CML cells was used to generate functional enrichment with Go-Elite Standalone software version 1.2 on the Gene Ontology Biological Process database included in Homo sapiens EnsMart77Plus (Ensembl - Biomart) update [21]. Unsupervised principal component analysis was performed on correlated gene expression profile with $\mathrm{R}$ package FactoMiner and p-value was calculated by group discrimination on the first principal component axis. The functional interaction network was built with functional relations identified during enrichment analysis with Cytoscape software version 3.2.1 [22]. 


\section{Scatter dot plots, boxplots, and statistical analysis}

Data from ENOX2 gene expression or protein concentration in plasma were expressed as scatter dot plots or boxplots with medians. They were generated using GraphPad Prism version 8.0 (GraphPad Software, San Diego, CA). Welch's t-test determined statistical significance between data groups. Differences are considered significant at $\mathrm{p}<0.05$. 


\section{Results}

\section{ENOX2 mRNA is overexpressed in BCR-ABL1-expressing UT-7 cell lines}

We conducted a transcriptome assay to identify genes up- or down-regulated in $B C R-A B L 1$ expressing UT-7 cell lines. To this end, we compared the UT-7/11 cell line ( $n=3)$, which expressed high levels of BCR-ABL1 protein, to parental UT-7 (UT7/p, n=3). We focused on ENOX2 mRNA, which was not previously known to be over-expressed in BCR-ABL1-positive leukemia. In our experiments, ENOX2 was significantly up-regulated (X 2.4, p=0.0012) in the $B C R-A B L 1$ expressing cell line (Fig 1).

\section{ENOX2 mRNA expression is increased in primary cells from patients at diagnosis}

To validate these preliminary results obtained in UT7 cells transduced with $B C R-A B L 1$, we examined ENOX2 mRNA expression by qRT-PCR in the blood samples from a cohort of CP-CML patients at diagnosis $(n=36)$ and a series of healthy donors $(n=27)$. As shown in Fig 2, levels of ENOX2 mRNA were significantly increased in samples from CML patients at diagnosis $(\mathrm{p}<0.0001)$ compared to healthy donors, with a fold change of 4.75 . In this cohort, we did not find any correlation between ENOX2 mRNA expression and Sokal score, or patient outcomes (achievement of a deep molecular response or sustained TFR after TKI withdrawal).

\section{BCR-ABL1 induces the production of ENOX2 protein in UT7 and TET-inducible Ba/F3 BCR-ABL1 cell lines}

Three UT-7 cell lines were first used to analyze the presence of ENOX2 protein by westernblots (parental UT-7, UT-7/11 and UT-7/T315I). We generated UT-7/11 and UT-7/T315I cell lines several years ago by retroviral transduction of wild-type or T315I-mutated $B C R-A B L 1$ in the GMCSF-dependent parental UT-7 cell line. In these two cell line models, the $B C R-A B L 1$ expression renders these cells GM-CSF-independent [13]. As can be expected, Fig 3a confirms the presence of BCR-ABL1 protein in UT-7/11 and UT-7/T315I cell lines, in contrast to parental UT-7. Concerning ENOX2, high protein levels were produced in the $B C R-A B L 1$-expressing UT-7 cell line (native UT-7/11 and mutated-UT-7/T315I) compared to UT-7/p control (Fig 3b). 
To ensure that ENOX2 overexpression would be related to the presence of BCR-ABL1, we used a $\mathrm{Ba} / \mathrm{F} 3$ cell line transduced with $B C R-A B L 1$ under the control of the TET promoter $(\mathrm{BaF} / \mathrm{p} 210 \sin 1.55)$. This inducible model was appropriate insofar as the BCR-ABL1 protein was inhibited by doxycycline (Fig 3c). Decreased ENOX2 protein expression was also observed in response to doxycycline added to the culture medium (Fig 3d). As can be seen in Figs 3c and 3d, BCR-ABL1 and ENOX2 are re-expressed at day 12 upon washing out doxycycline from the cell medium. Consequently, ENOX2 overexpression appeared to be related to the presence of BCRABL1 insofar as inhibition of BCR-ABL1 expression in the TET-inducible Ba/F3 model led to a reduction in ENOX2 protein synthesis.

Finally, we wondered whether the expression of ENOX2 in CML cells was a tyrosine kinasedependent event. We have previously demonstrated the reduction of phospho-Tyr BCR-ABL1 protein upon Imatinib treatment in $B C R-A B L 1$-expressing UT7 cells [23]. In this study, western blot experiments showed that ENOX2 protein expression was reduced in the UT7/11 cell line treated with Imatinib 1 microM for 6, 18, and 24 hours (Fig 4a). Same experiments performed on UT-7/p cell line showed no modification of ENOX2 expression (Fig 4b).

\section{ENOX2 protein levels are significantly increased in the plasma of CML patients}

As ENOX2 protein can be released from tumor cells into extracellular fluids, we determined its concentration in the plasma of CML patients at diagnosis $(n=41)$ compared to healthy controls $(\mathrm{n}=28)$ using an ELISA method. As presented in Fig 5, a significant increase in plasma ENOX2 protein levels $(\mathrm{p}<0.0001)$ was shown in CP-CML patients at diagnosis before TKI therapy. The extended frequency distribution of ENOX2 protein levels is undoubtedly due to heterogeneity between patients. Furthermore, no correlation was found between ENOX2 protein levels in the plasma and white blood cell (WBC) count at diagnosis (S4 Fig).

\section{ENOX2 mRNA overexpression is characteristic of the chronic phase of CML}

We reanalyzed a publicly available transcriptome dataset from CML patients during the different phases of their disease (GSE4170). In this work, the authors performed microarray analyses to evaluate CML patients' gene expression profiles in the chronic, accelerated, and blast 
phases. ENOX2 mRNA expression data were retrieved from the GE0 database and analyzed independently. For each patient, ENOX2 mRNA expression was shown using normal immature $\mathrm{CD} 4^{+}$cells as reference (median ENOX2 expression of normal CD34+ cells was subtracted from each sample). As shown in Fig 6, ENOX2 mRNA up-regulation was observed in this independent study for all CP-CML patients. In addition, ENOX2 was significantly overexpressed in CP-CML patients, as compared to patients in the accelerated $(\mathrm{p}<0.0001)$ and blast phases $(\mathrm{p}<0.0001)$. Interestingly, ENOX2 expression in the accelerated and blast crises is very similar to that of normal CD34+ cells and appears heterogeneous.

\section{The mRNA expression of ENOX2 and related genes distinguishes the chronic phase of CML from advanced phases}

Exploiting the GSE4170 transcriptome dataset, we then tried to discover genes positively correlated to ENOX2 mRNA expression and to highlight a potential link between the ENOX2 transcriptional program and BCR-ABL1-mediated leukemogenesis. Pavlidis template matching algorithm used with ENOX2 as a predictor highlighted 301 related genes with a positive r correlation coefficient greater than 0.80 and a p-value threshold less than $p<1 E-6$ (S2 Table). The high level of correlation to ENOX2 mRNA expression is illustrated for eight potentially relevant protein-coding genes (EPHB3, HEYL, ERK1, PlGF, FAK, RHOG, THY1, and TRIB1) in S5 Fig. Heatmap and parallel coordinate plot revealed that the high mRNA expression level of these 301 genes was characteristic of the chronic phase of CML (Fig 7a). Unsupervised principal component analysis performed with ENOX2 pattern matching gene expression profile allowed highly significant discrimination of the chronic phase from accelerated and blast phases (Fig 7b, $\mathrm{p}<0.0001)$.

\section{Several proteins of a potential ENOX2 network can be involved in the CML context in crucial biological processes}

Functional enrichment performed with ENOX2 pattern matching on the Gene Ontology Biological Process database emphasized 49 genes (out of 301) known to be involved in essential cell processes (Fig 8a). In the context of ENOX2 mRNA overexpression in CP-CML, several major biological functions appear to be activated: angiogenesis, NOTCH signaling, cell morphogenesis differentiation, circadian rhythm, RAS signaling, cell proliferation, G-protein receptor pathways, 
integrin-mediated signaling, carbohydrate homeostasis, stress-activated protein kinase, and RHO GTPase activities (Fig 8b, S3 Table). 


\section{Discussion}

The involvement of ENOX2 in BCR-ABL1-positive leukemias, as indicated by PubMed searches, has yet to be shown. In this work, we established that ENOX2 mRNA was overexpressed in both experimental models of BCR-ABL1-induced cell transformation and primary leukemic cells from newly diagnosed CP-CML patients. Regarding the in vitro model, we did not use CML cell lines derived from patients in blast crisis, such as the erythrocytic K562, the myelocytic KCL22 or the erythro-megakaryocytic LAMA-84, since they present an extreme variability in their characteristics of cell clones and in their BCR-ABL1 expression. Moreover, there is no counterpart of these cells without $B C R-A B L 1$ expression (as opposed to UT7 model). Western-blots analyses confirmed the presence of higher levels of ENOX2 protein in $B C R-A B L 1$-expressing murine and human cell lines. This overexpression is directly influenced by the presence of BCR-ABL1 oncoprotein and related to its constitutive tyrosine kinase activity. Using a large number of plasma samples from both CML patients and healthy donors, we went on to show a significant increase in plasma ENOX2 levels in CML patients at diagnosis. Reanalyzing a transcriptomic dataset from a previously reported gene profiling study [18], we observed that ENOX2 mRNA expression is restricted to the chronic phase of the disease. Nevertheless, we could not determine here whether ENOX2 is a direct or an indirect target of BCR-ABL1.

Several lines of experimental data indicate that ENOX2 protein expression in adult cells appears to be restricted to cancer cells. Although ENOX2 mRNA was detectable in both nonmalignant and malignant cells, the ENOX2 gene would be translated only during early embryogenesis and cancer development. Therefore, ENOX2 physiologic function appears to be restricted to the embryonic period [24], in which this oncofetal protein located at the plasma membrane has an oscillating enzymatic activity. Little is known about the reappearance and the oncogenic function of ENOX2 in adult cells. However, it has been shown that ENOX2 proteins are constitutively activated in cancers and could promote cell proliferation [25-27].

As they are not firmly anchored into the cell membrane, ENOX2 proteins can be released into extracellular fluids. This circulating form has been detected in the sera of patients suffering from various tumors [28], whereas it is present only at very low levels in healthy subjects [29]. A twodimensional gel electrophoretic separation (ONCOblot) reveals unique profiles that are seemingly specific to a type of cancer $[17,28]$. In the present study, high levels of circulating ENOX2 protein detected in plasma from CML patients at diagnosis are consistent with these data.

In silico reanalyses suggest that mRNA expression of several genes is positively correlated to ENOX2 expression in a BCR-ABL1 context, thereby highlighting critical biological functions 
(angiogenesis, NOTCH signaling, cell morphogenesis differentiation, circadian rhythm, RAS signaling, cell proliferation, G-protein receptor pathways, integrin-mediated signaling, carbohydrate homeostasis, stress-activated protein kinase, and RHO GTPase activities). These data are based on mRNA expression and not on the presence/activity of the proteins. However, these results on a substantial number of individual genes are highly significant, and it is quite unlikely that all these genes are not translated into functional proteins. Consequently, high ENOX2 mRNA expression probably goes along with the activation of cell proliferation and differentiation through genes encoding proteins from different pathways. ENOX2 overexpression has been linked to cell proliferation, migration, and increased expression of mesenchymal markers in some cancers [27]. Interestingly, these data are in line with the fundamental characteristics of CML dysregulation [30].

Among the genes found to be positively correlated with ENOX2 mRNA expression in a CML context, some deserve further discussion. RAC2 GTPases are known to be critical regulators of BCR-ABL1-mediated leukemogenesis [31]. Activation of the MAP-kinase ERK through the RASinduced pathway has been implicated in cell proliferation and differentiation in K562 cells [32]. The focal adhesion kinase (FAK), phosphorylated by BCR-ABL1, plays a crucial role in CML cells insofar as its silencing inhibits the leukemogenesis process [33]. The role of TRIB1 (tribbles homolog 1) serine/threonine kinase-like protein in CML pathogenesis has also been pointed out [34]. On the other hand, NOTCH1 has been shown to interact with BCR-ABL1 in CD34+ cells from CP-CML patients [35]. Finally, $B C R-A B L 1$-expressing cells could secrete angiogenic factors [36]. In this respect, it has been shown that the BCR-ABL1 oncoprotein induces the production of placental growth factor (PGF or PlGF) by bone marrow stromal cells to support in situ angiogenesis and promote cell proliferation [37].

All these data suggest that ENOX2 could play a role in CML's pathogenesis in a BCR-ABL1dependent manner. In addition to this potential biological feature, could ENOX2 be a surrogate marker or even a therapeutic target? Based on our experiments, we can say that ENOX2 is the first secreted biomarker described in CML. On the other hand, during our study we did not find any relationship between ENOX2 mRNA expression or ENOX2 plasma levels and the clinical course or the most relevant biological parameters. Some anti-oxidant agents (capsaicin, omega-3 polyunsaturated fatty acids, or synthetic isoflavone) could exert an anti-tumor effect by inhibiting ENOX2 enzymatic activity [38-40]. All of these agents (and perhaps others) could represent a potential ENOX2-targeted therapy in malignant diseases. However, in CML, a majority of patients treated with TKIs achieve a sustained molecular response. Therefore, in most cases, CML treatment does not require additional drugs. Nevertheless, two circumstances may require other 
therapeutic options: complete resistance to all available TKIs, or the persistence of quiescent leukemic stem cells [41]. The potential interest of ENOX2 as a druggable target in these contexts calls for further exploration.

\section{Conclusions}

It is now well-established that ENOX2 protein is present during the embryonic period, almost absent in normal adult cells, and reappears in most cancer cells. In physiological conditions, ENOX2 fulfills functions essential to the development of early embryos. During pathological circumstances, the same enzymatic functions could contribute to growth deregulation of cancer cells. Based on our results, we propose that BCR-ABL1 up-regulates ENOX2 in the chronic phase of CML. To the best of our knowledge, the association between the reactivation of ENOX2 in adult cells and deregulated tyrosine kinase activity was never previously observed. That said, a link between BCR-ABL1 and the tumor-associated NADH oxidase ENOX2 has not been established. The hypothesis that some downstream BCR-ABL1 substrates could activate an irrelevant translation mechanism of ENOX2 variant transcripts can be put forward. 


\section{Acknowledgements}

The English of the manuscript was reviewed by Jeffrey Arsham, an American medical translator.

\section{Author's contributions}

Conceptualization, A.B.G., J.C.C. and A.G.T.; methodology, S.B.K., M.V. and N.S.; experiments, S.B.K., M.V. and N.S.; bioinformatic analysis, C.D.; validation, J.C.C., A.B.G. and A.G.T.; clinical investigation, E.C., H.G.A, H.G.B and A.G.T.; writing—original draft preparation, J.C.C. and A.G.T.; writing-review and editing, J.C.C., N.S., E.C., A.B.G and A.G.T.; supervision, A.G.T. All authors have read and agreed to the published version of the manuscript. 


\section{References}

1. Bower H, Björkholm M, Dickman PW, Höglund M, Lambert PC, et al. (2016) Life Expectancy of Patients With Chronic Myeloid Leukemia Approaches the Life Expectancy of the General Population. J Clin Oncol. 34: 2851-2857.

2. Hehlmann R, Lauseker M, Saußele S, Pfirrmann M, Krause S, et al. (2017) Assessment of imatinib as first-line treatment of chronic myeloid leukemia: 10-year survival results of the randomized CML study IV and impact of non-CML determinants. Leukemia. 31: 2398-2406.

3. Hochhaus A, Baccarani M, Silver RT, Schiffer C, Apperley JF, et al. (2020) European LeukemiaNet 2020 recommendations for treating chronic myeloid leukemia. Leukemia. 34: 966-984.

4. Chereda B, Melo JV. (2015) Natural course and biology of CML. Ann Hematol. 94 Suppl 2: S107-21.

5. Cilloni D, Saglio G. (2012) Molecular pathways: BCR-ABL. Clin Cancer Res. 18: 930-937.

6. Dkhissi F, Aggoune D, Pontis J, Sorel N, Piccirilli N, et al. (2015) The downregulation of BAP1 expression by BCR-ABL reduces the stability of BRCA1 in chronic myeloid leukemia. Exp Hematol. 43: 775-780.

7. Girerd S, Tosca L, Herault O, Vignon C, Biard D, et al. (2018) Superoxide dismutase 2 (SOD2) contributes to genetic stability of native and T315I-mutated BCR-ABL expressing leukemic cells. Biochem Biophys Res Commun. 498: 715-722.

8. Desterke C, Voldoire M, Bonnet ML, Sorel N, Pagliaro S, et al. (2018) Experimental and integrative analyses identify an ETS1 network downstream of BCR-ABL in chronic myeloid leukemia (CML). Exp Hematol. 64: 71-83.e8.

9. Chueh PJ, Kim C, Cho N, Morré DM, Morré DJ. (2002) Molecular cloning and characterization of a tumor-associated, growth-related, and time-keeping hydroquinone (NADH) oxidase (tNOX) of the HeLa cell surface. Biochemistry. 41: 3732-3741. 
10. Morré DJ, Chueh PJ, Pletcher J, Tang X, Wu LY, et al. (2002) Biochemical basis for the biological clock. Biochemistry. 41: 11941-11945.

11. Morré DJ, Morré DM. (2003) Cell surface NADH oxidases (ECTO-NOX proteins) with roles in cancer, cellular time-keeping, growth, aging and neurodegenerative diseases. Free Radic Res. 37: 795-808.

12. Komatsu N, Nakauchi H, Miwa A, Ishihara T, Eguchi M, et al. (1991) Establishment and characterization of a human leukemic cell line with megakaryocytic features: dependency on granulocyte-macrophage colony-stimulating factor, interleukin 3, or erythropoietin for growth and survival. Cancer Res. 51: 341-348.

13. Issaad C, Ahmed M, Novault S, Bonnet ML, Bennardo T, et al. (2000) Biological effects induced by variable levels of BCR-ABL protein in the pluripotent hematopoietic cell line UT-7. Leukemia. 14: 662-670.

14. Aggoune D, Tosca L, Sorel N, Bonnet ML, Dkhissi F, et al. (2014) Modeling the influence of stromal microenvironment in the selection of ENU-induced BCR-ABL1 mutants by tyrosine kinase inhibitors. Oncoscience. 1: 57-68.

15. Dugray A, Geay JF, Foudi A, Bonnet ML, Vainchenker W, et al. (2001) Rapid generation of a tetracycline-inducible $\mathrm{BCR}-\mathrm{ABL}$ defective retrovirus using a single autoregulatory retroviral cassette. Leukemia. 15: 1658-1662.

16. Tang X, Tian Z, Chueh PJ, Chen S, Morré DM, et al. (2007) Alternative splicing as the basis for specific localization of tNOX, a unique hydroquinone (NADH) oxidase, to the cancer cell surface. Biochemistry. 46: 12337-12346.

17. Morré DJ, Hostetler B, Taggart DJ, Morré DM, Musk AW, et al. (2016) ENOX2-based early detection (ONCOblot) of asbestos-induced malignant mesothelioma 4-10 years in advance of clinical symptoms. Clin Proteomics. 13: 2.

18. Radich JP, Dai H, Mao M, Oehler V, Schelter J, et al. (2006) Gene expression changes associated with progression and response in chronic myeloid leukemia. Proc Natl Acad Sci U S A. 103: 2794-2799. 
19. Pavlidis P, Noble WS. (2001) Analysis of strain and regional variation in gene expression in mouse brain. Genome Biol. 2: RESEARCH0042.

20. Culhane AC, Thioulouse J, Perrière G, Higgins DG. (2005) MADE4: an R package for multivariate analysis of gene expression data. Bioinformatics. 21: 2789-2790.

21. Zambon AC, Gaj S, Ho I, Hanspers K, Vranizan K, et al. (2012) GO-Elite: a flexible solution for pathway and ontology over-representation. Bioinformatics. 28: 2209-2210.

22. Cline MS, Smoot M, Cerami E, Kuchinsky A, Landys N, et al. (2007) Integration of biological networks and gene expression data using Cytoscape. Nat Protoc. 2: 2366-2382.

23. Deutsch E, Jarrousse S, Buet D, Dugray A, Bonnet ML, et al. (2003) Down-regulation of BRCA1 in BCR-ABL-expressing hematopoietic cells. Blood. 101: 4583-4588.

24. Cho N, Morré DJ. (2009) Early developmental expression of a normally tumor-associated and drug-inhibited cell surface-located NADH oxidase (ENOX2) in non-cancer cells. Cancer Immunol Immunother. 58: 547-552.

25. Bruno M, Brightman AO, Lawrence J, Werderitsh D, Morré DM, et al. (1992) Stimulation of NADH oxidase activity from rat liver plasma membranes by growth factors and hormones is decreased or absent with hepatoma plasma membranes. Biochem J. 284: 625-628.

26. Yagiz K, Snyder PW, Morré DJ, Morré DM. (2008) Cell size increased in tissues from transgenic mice overexpressing a cell surface growth-related and cancer-specific hydroquinone oxidase, $\mathrm{tNOX}$, with protein disulfide-thiol interchange activity. J Cell Biochem. 105: 1437-1442.

27. Zeng ZM, Chuang SM, Chang TC, Hong CW, Chou JC, et al. (2012) Phosphorylation of serine-504 of tNOX (ENOX2) modulates cell proliferation and migration in cancer cells. Exp Cell Res. 318: 1759-1766.

28. Hostetler B, Weston N, Kim C, Morré DM, Morré DJ. (2009) Cancer Site-Specific Isoforms of ENOX2 (tNOX), A Cancer-Specific Cell Surface Oxidase. Clinical Proteomics. 5: 46-51. 
29. Morré DJ, Hostetler B, Weston N, Kim C, Morré DM. (2008) Cancer type-specific tNOX isoforms: A putative family of redox protein splice variants with cancer diagnostic and prognostic potential. Biofactors. 34: 201-207.

30. Clarkson BD, Strife A, Wisniewski D, Lambek C, Carpino N. (1997) New understanding of the pathogenesis of CML: a prototype of early neoplasia. Leukemia. 11: 1404-1428.

31. Thomas EK, Cancelas JA, Zheng Y, Williams DA. (2008) Rac GTPases as key regulators of p210-BCR-ABL-dependent leukemogenesis. Leukemia. 22: 898-904.

32. Woessmann W, Mivechi NF. (2001) Role of ERK activation in growth and erythroid differentiation of K562 cells. Exp Cell Res. 264: 193-200.

33. Le Y, Xu L, Lu J, Fang J, Nardi V, et al. (2009) FAK silencing inhibits leukemogenesis in BCR/ABL-transformed hematopoietic cells. Am J Hematol. 84: 273-278.

34. Albano F, Zagaria A, Anelli L, Coccaro N, Impera L, et al. (2013) Gene expression profiling of chronic myeloid leukemia with variant $\mathrm{t}(9 ; 22)$ reveals a different signature from cases with classic translocation. Mol Cancer. 12: 36.

35. Aljedai A, Buckle AM, Hiwarkar P, Syed F. (2015) Potential role of Notch signalling in CD34+ chronic myeloid leukaemia cells: cross-talk between Notch and BCR-ABL. PLoS One. 10: e0123016.

36. Janowska-Wieczorek A, Majka M, Marquez-Curtis L, Wertheim JA, Turner AR, et al. (2002) Bcr-abl-positive cells secrete angiogenic factors including matrix metalloproteinases and stimulate angiogenesis in vivo in Matrigel implants. Leukemia. 16: 1160-1166.

37. Schmidt T, Kharabi Masouleh B, Loges S, Cauwenberghs S, Fraisl P, et al. (2011) Loss or inhibition of stromal-derived PIGF prolongs survival of mice with imatinib-resistant BcrAbl1(+) leukemia. Cancer Cell. 19: 740-753.

38. Morre J, Morré DM, Brightmore R. (2010) Omega-3 but not omega-6 unsaturated fatty acids inhibit the cancer-specific ENOX2 of the HeLa cell surface with no effect on the constitutive ENOX1. J Diet Suppl. 7: 154-158. 
39. Morré DJ, Korty T, Meadows C, Ades LM, Morré DM. (2014) ENOX2 target for the anticancer isoflavone ME-143. Oncol Res. 22: 1-12.

40. Islam A, Su AJ, Zeng ZM, Chueh PJ, Lin MH. (2019) Capsaicin Targets tNOX (ENOX2) to Inhibit G1 Cyclin/CDK Complex, as Assessed by the Cellular Thermal Shift Assay (CETSA). Cells. 8: 1275.

41. Chomel JC, Turhan AG. (2011) Chronic myeloid leukemia stem cells in the era of targeted therapies: resistance, persistence and long-term dormancy. Oncotarget. 2: 713-727. 


\section{Figure Legends.}

Fig 1. ENOX2 up-regulation in BCR-ABL1-positive UT-7/11 cell line. Significant overexpression of ENOX2 mRNA is observed in UT-7/11 (transfected by BCR-ABL1) compared with UT-7 controls. P-values were calculated with a two-sided Welch's t-test.

Fig 2. ENOX2 mRNA is overexpressed in primary cells from CML patients. The scatter dot plot shows ENOX2 mRNA expression in whole blood samples from CML patients at diagnosis $(\mathrm{n}=36)$ compared with healthy donors $(\mathrm{n}=27)$. P-values were calculated with a two-sided Welch's t-test.

Fig 3. ENOX2 protein is up-regulated by BCR-ABL1 in UT-7/11 and TET-inducible Ba/F3 cell lines. (a) Western blot control of BCR-ABL1 induction after the transfection of the $B C R$ $A B L 1$ fusion oncogene in the UT-7/11 cell line (non-mutated UT-7/11 and mutated UT7/T315I) as compared to parental UT-7. (b) High ENOX2 up-regulation is observed by western blot analysis in transfected BCR-ABL1 UT-7 cells (non-mutated UT-7/11 and mutated UT7/T315I). (c) Western blot verification of the inducible $\mathrm{Ba} / \mathrm{F} 3(\mathrm{BaF} / \mathrm{p} 210$ sin 1.55$)$ cell line expressing BCRABL1 under the control of a TET promoter. As shown, cells were cultured in the presence of doxycycline for 2, 3, 5, 7, and 9 days. As can be seen in the Figure, upon washing out doxycycline from the cell medium, BCR-ABL1 is re-expressed at day 12. (d) ENOX2 up-regulation in the inducible $\mathrm{Ba} / \mathrm{F} 3$ cell line is dependent on the presence of BCR-ABL1. As observed in the Figure, upon washing out doxycycline from the cell medium, ENOX2 is re-expressed at day 12.

Fig 4. ENOX2 protein up-regulation depends on the BCR-ABL1 tyrosine kinase-activity. a) Western blot analysis performed in the UT-7/11 cell line under tyrosine kinase inhibition conditions (Imatinib 1 microM for 6, 18, 24 hours) shows the reduction of the ENOX2 protein expression, suggesting that its expression is dependent on the kinase activity of BCR-ABL1. b) Western blot analysis performed in the UT-7/p cell line as control showing no modification of ENOX2 expression upon inhibition of BCR-ABL1 tyrosine kinase activity.

Fig 5. Secreted ENOX2 protein is detected in blood from CP-CML patients at diagnosis. The boxplot shows a high ENOX2 protein level in blood plasma from CP-CML patients at diagnosis $(n=41)$ compared with healthy donors $(n=28)$. The median and the 5\%, 25\%,75\%, and 95\% percentiles are shown in boxplot diagrams. Dots correspond to observations outside the range of adjacent values. P-values were calculated with a two-sided Welch's t-test. 
Fig 6. Relative ENOX2 gene expression during the different phases of CML using the GSE4170 GEO dataset. ENOX2 mRNA relative expressions in CML leukemic cells corresponding to patients in chronic phase (CP), accelerated phase (AP), and blast crisis (BC) were compared to normal immature $\mathrm{CD}^{+} 4^{+}$cells. P-values were calculated with a two-sided Welch's ttest.

Fig 7. The mRNA expression of ENOX2 and related genes allows discrimination of the chronic phase of CML from the more advanced phases of the disease. (a) Heatmap and parallel coordinate plot revealed 301 genes positively correlated to ENOX2 mRNA expression. Their high mRNA expression level appears to be characteristic of the chronic phase of CML. (b) Unsupervised principal component analysis performed with ENOX2 pattern matching gene expression profile distinguishes the chronic phase of CML from the accelerated and blast phases. Correlation p-value was evaluated for phase discrimination on the first principal axis; ellipses around the barycenter were estimated with $75 \%$ confidence.

Fig 8. A potential network correlated to ENOX2 gene expression is highlighted in CML cells. (a) Functional enrichment performed with ENOX2 pattern matching on the Gene Ontology Biological Process database reveals 49 genes (out of 301) known to be involved in essential cellular processes. Results are presented as a Cytoscape network view showing both biological functions and related genes. The color of nodes in the network is relative to the $\mathrm{Z}$-scores obtained during functional enrichment (from yellow for low Z-scores to purple for high Z-scores), the size of function nodes is relative to the number of genes enriched in the corresponding function mapped on the network. (b) Bar plots represent both the $\mathrm{Z}$ scores and the gene expression fold changes for the different molecular functions defined by the Gene Ontology Biological Process database. 


\section{Fig 1}

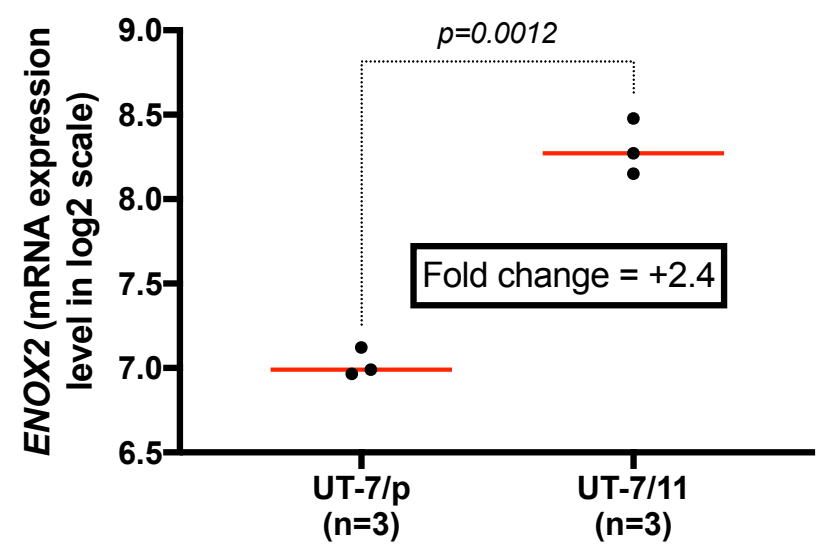




\section{Fig 2}

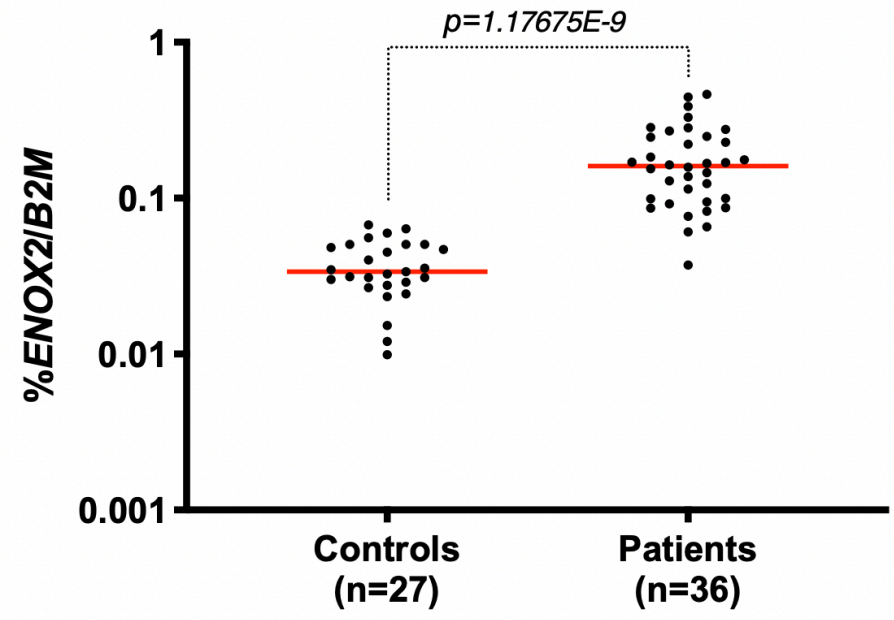




\section{Fig 3}
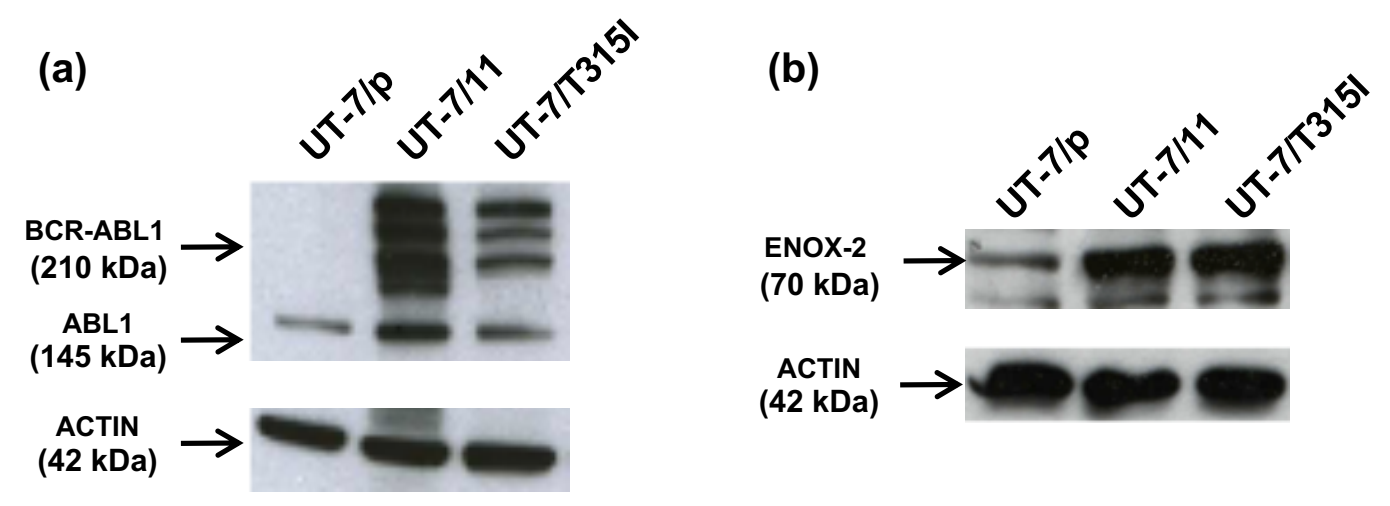

(c)
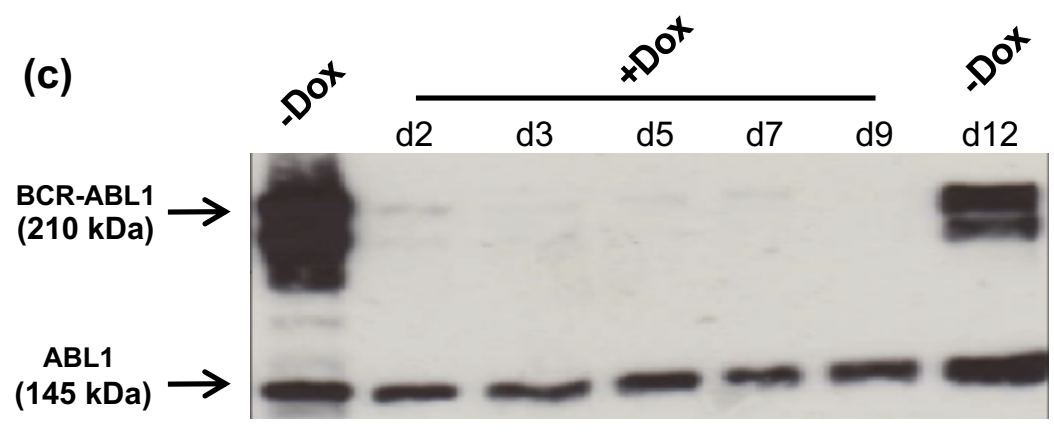

$\mathrm{BaF} / 3 \mathrm{p} 210 \sin 1.55$

(TET-inducible Ba/F3 BCR-ABL1)

(d)

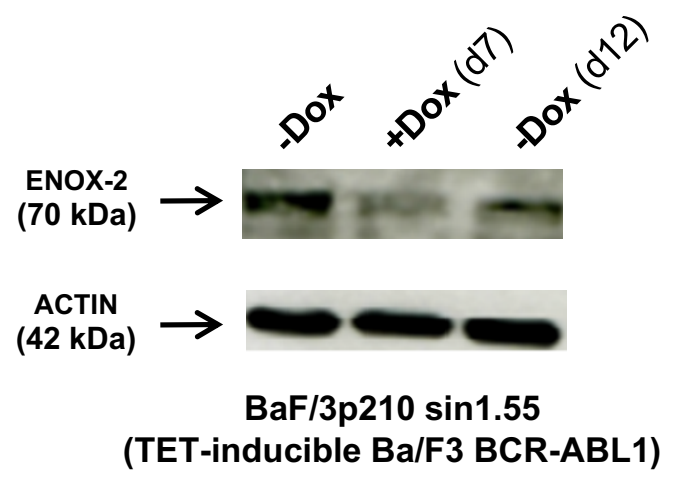




\section{Fig 4}

(a)

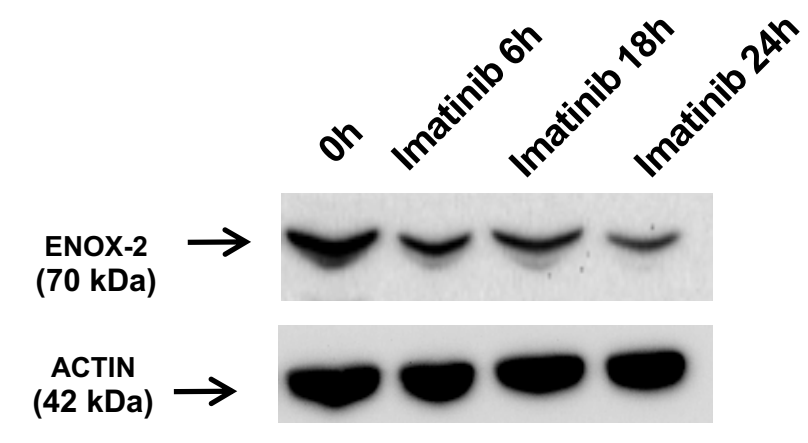

UT-7/11

(b)

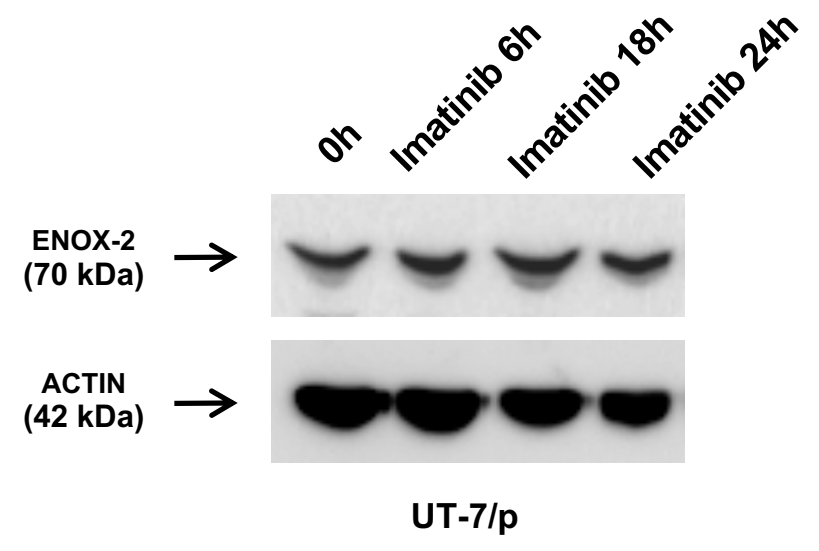




\section{Fig 5}

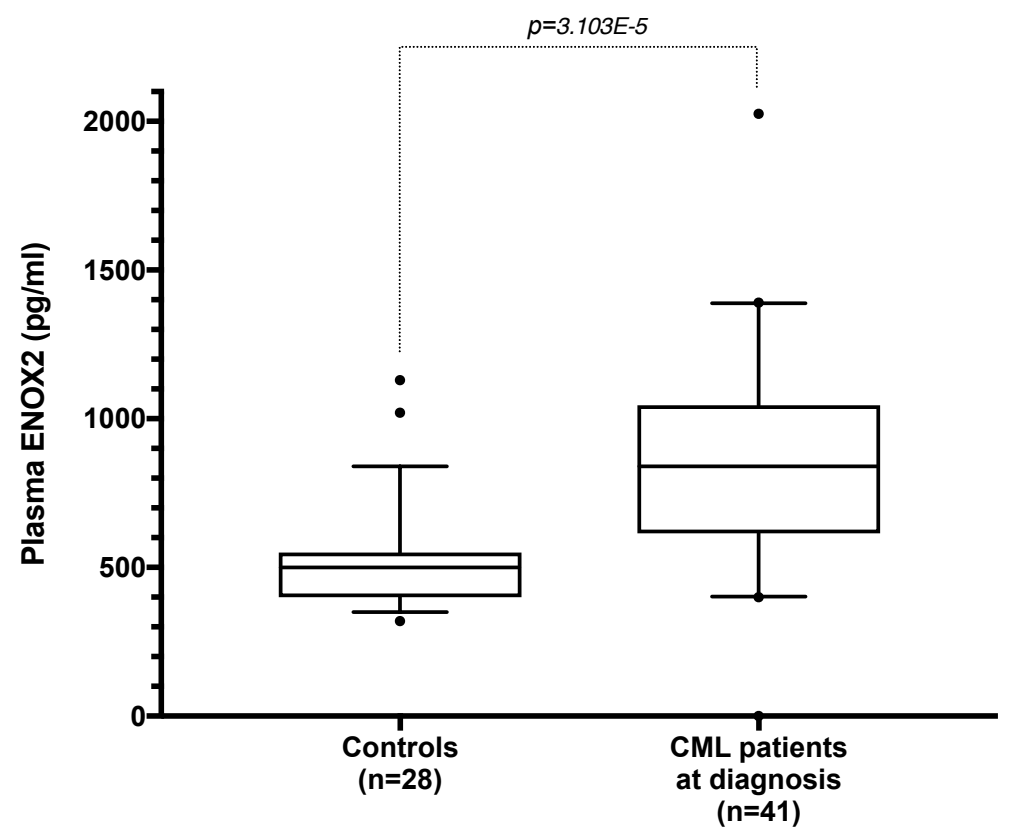


Fig 6

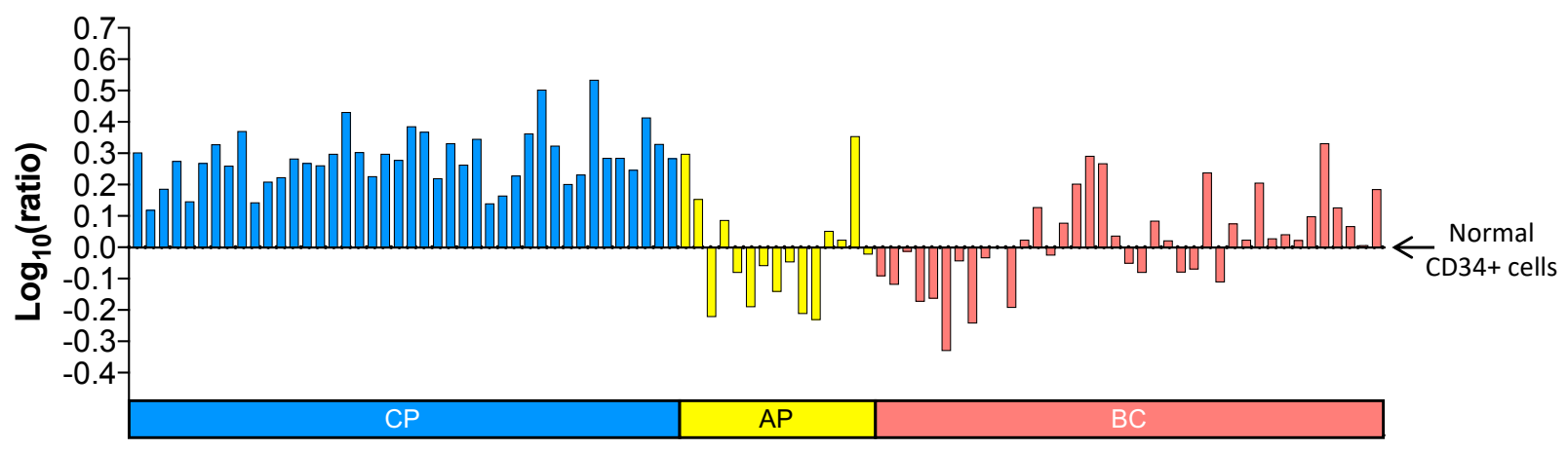




\section{Fig 7}

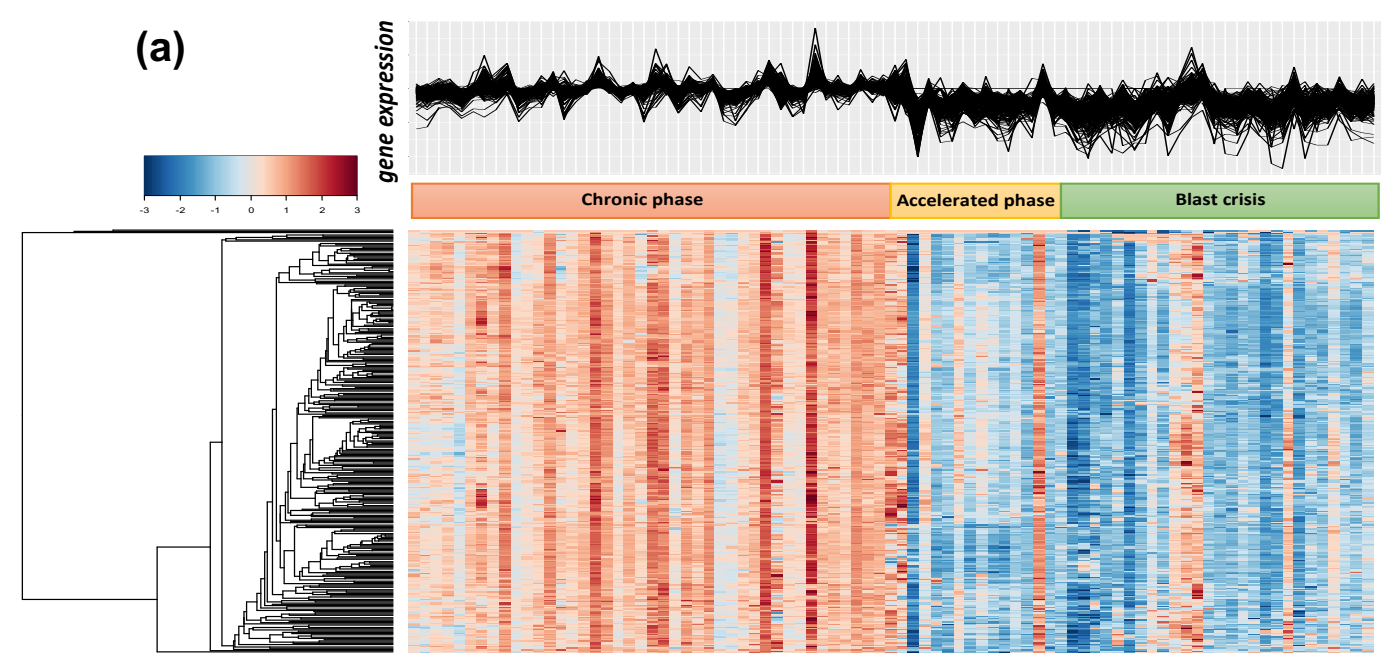

(b)

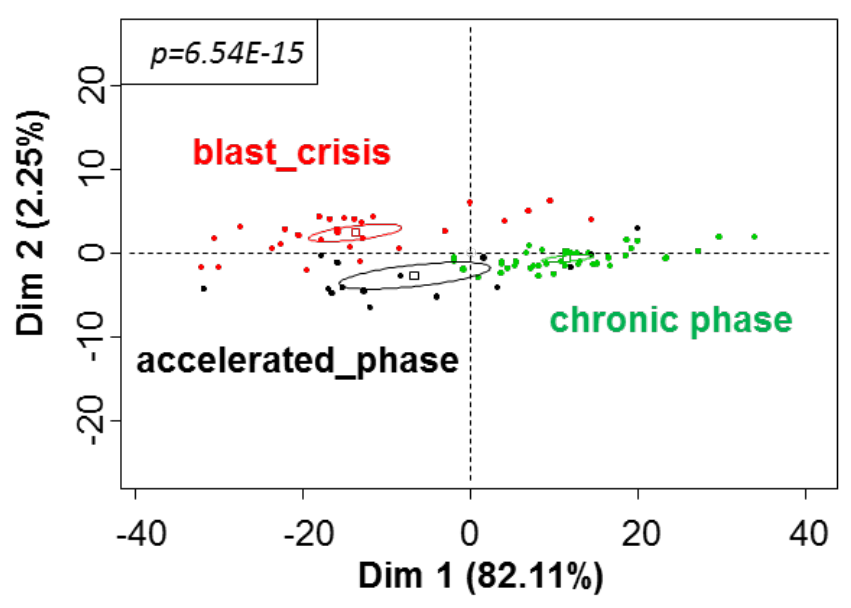




\section{Fig 8}

(a)

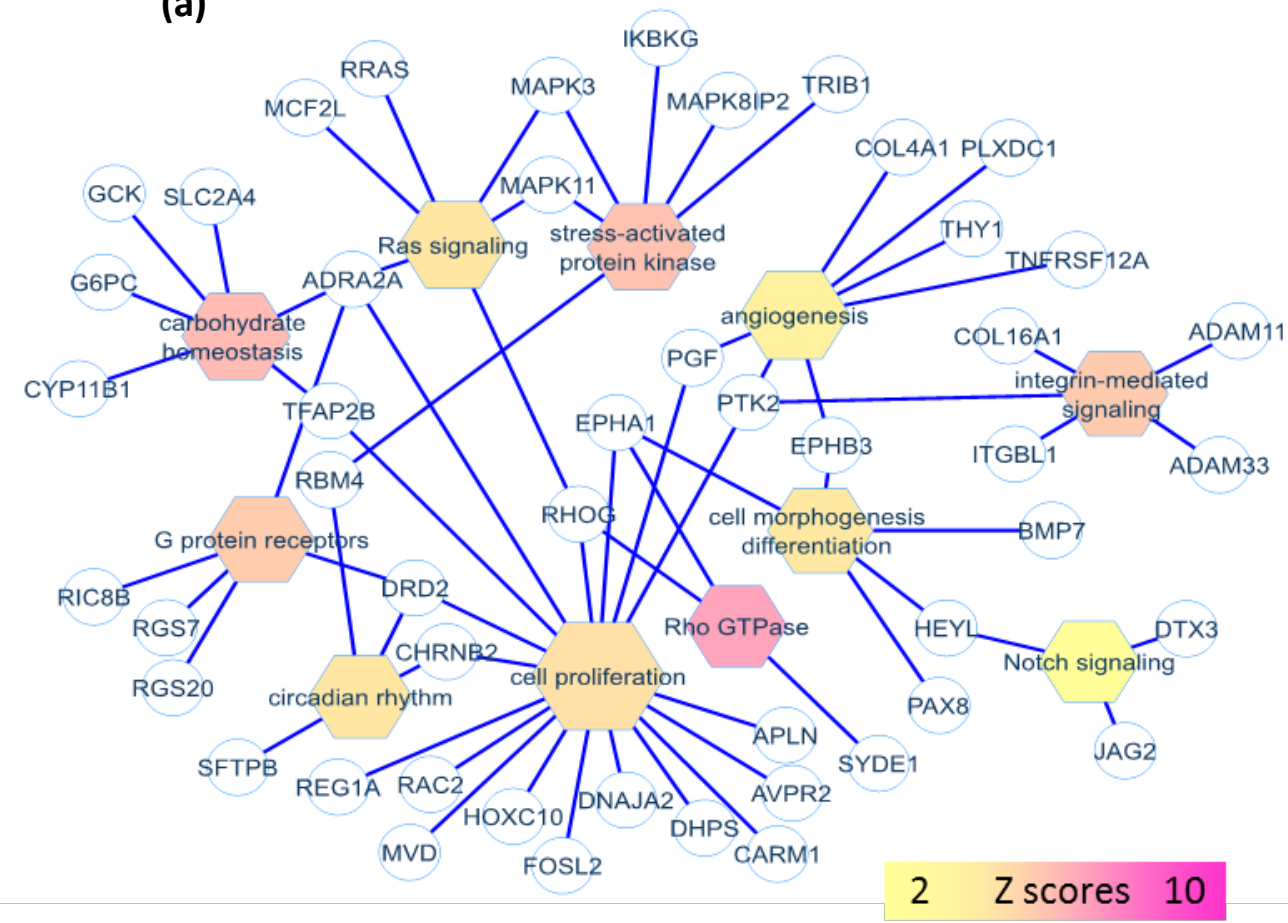

(b)

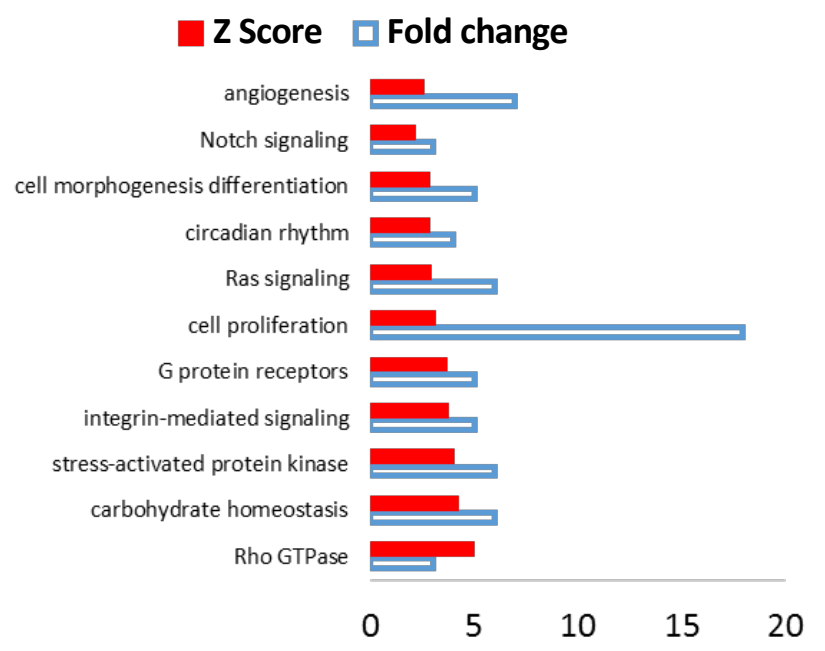




\section{Supporting information}

S1 Fig: Schematic representation of ENOX2 dimer functions at the plasma membrane of a cancer cell. ENOX2 combines two main enzymatic oscillatory activities (hydroquinone NADH oxidase and protein disulfide-thiol oxidoreductase) that alternate with a period length of approximately $22 \mathrm{~min}$, generating an ultradian cellular biological clock of 22 hours. According to Morré DJ, Morré DM. ECTO-NOX Proteins, Growth, Cancer, and Aging. Springer (2013).

S2 Fig: Schematic representation of some mature transcript types (as examples) and alternative splicing observed in the ENOX2 gene. Data came from REFSEQ mRNAs (NM_182314 taken as reference for exon numbering). The blue bar represents exon 10-11 boundaries for qRT-PCR experiments using ENOX2 TaqMan pre-developed assay reagent (Hs00197268_m1). Theoretical derived molecular weights of proteins translated from the open reading frame of the different mRNA isoforms are given as an indication. Exons in red and orange correspond to full-length cDNA and exons potentially translated in case of exon 7 skipping (alternative translation initiation sites), respectively.

S3 Fig: Amino-acid and nucleotide sequences of full-length ENOX2. Amino-acid and nucleotide numeration correspond to the theoretical protein of $610 \mathrm{aa}(70 \mathrm{kDa})$. The sequences underlined in blue indicate the most likely Kozak consensus for protein translation initiation. Sequences in red correspond to exon 7 (exon 4 in another nomenclature). In the case of exon 7 skipping (NM_183314 numbering), alternative translation initiation sites, such as the $\mathrm{M}^{231}$, initiate the production of various tumor-associated ENOX2 proteins of lower molecular weight.

S4 Fig: Analysis of a potential relationship between ENOX2 protein levels and white blood cells (WBCs). No correlation was observed between ENOX2 plasma concentrations and WBC count in CML patients at diagnosis. 
S5 Fig: Several potentially relevant protein-coding genes display a mRNA expression significantly correlated to ENOX2 mRNA expression. Linear regression reveals a high positive correlation degree between ENOX2 and EPHB3, HEYL, ERK1, PlGF, FAK, RHOG, THY1, TRIB1 gene mRNA expression. The $\mathrm{r} 2$ and $\mathrm{p}$ parameters are shown on each graph.

S1 Table: Patient characteristics (cohort ENOX2 mRNA expression).

S2 Table: Genes correlated to ENOX2 mRNA expression.

S3 Table: Proteins of ENOX2 potential network involved in critical biological processes. 
S1 Fig: Schematic representation of ENOX2 dimer functions at the plasma membrane of a cancer cell.

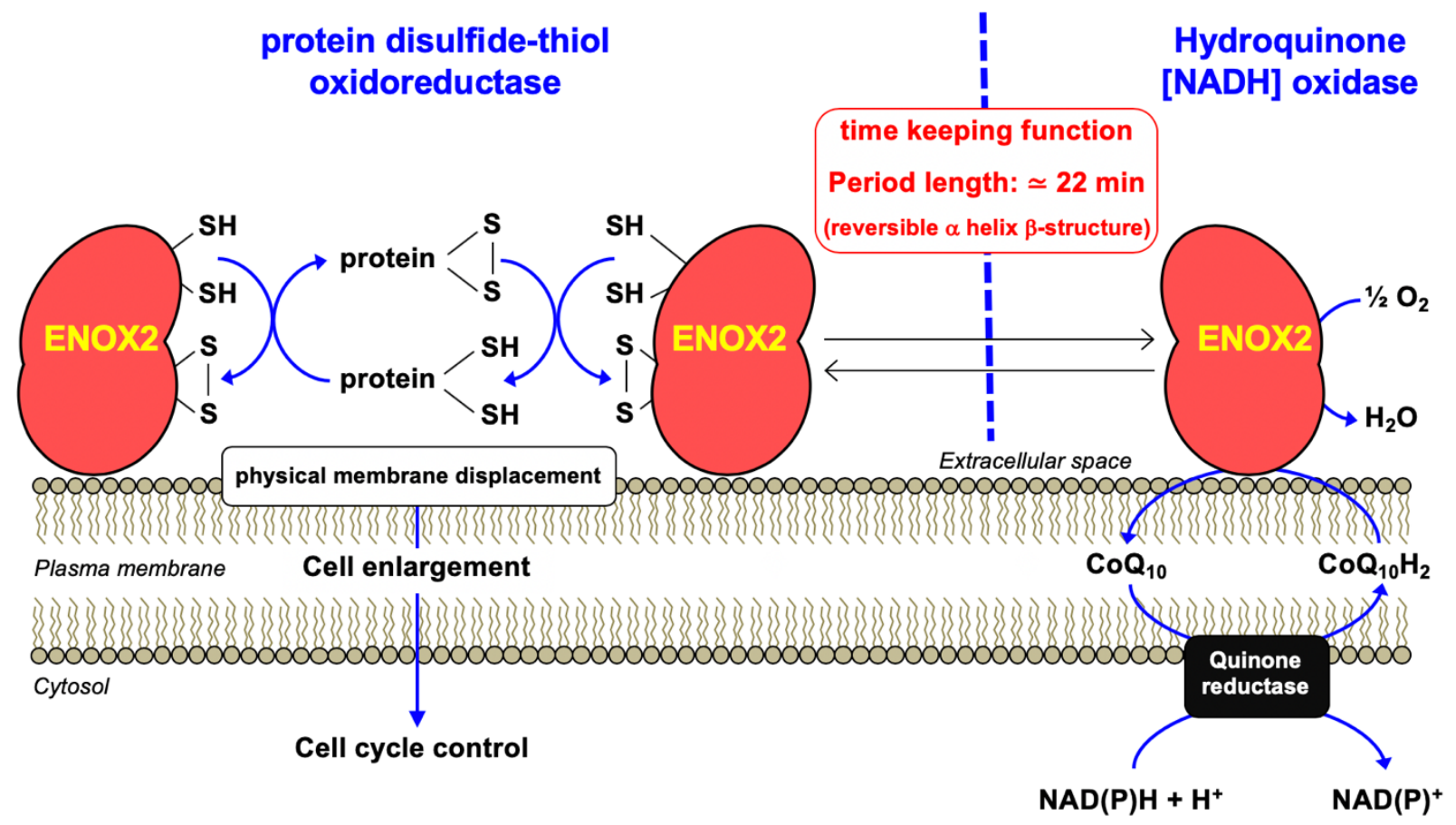

ENOX2 combines two main enzymatic oscillatory activities (hydroquinone NADH oxidase and protein disulfide-thiol oxidoreductase) that alternate with a period length of approximately $22 \mathrm{~min}$, generating an ultradian cellular biological clock of 22 hours. According to Morré DJ, Morré DM. ECTO-NOX Proteins, Growth, Cancer, and Aging. Springer (2013). 
S2 Fig: Schematic representation of some mature transcript types (as examples) and alternative splicing observed in the ENOX2 gene.

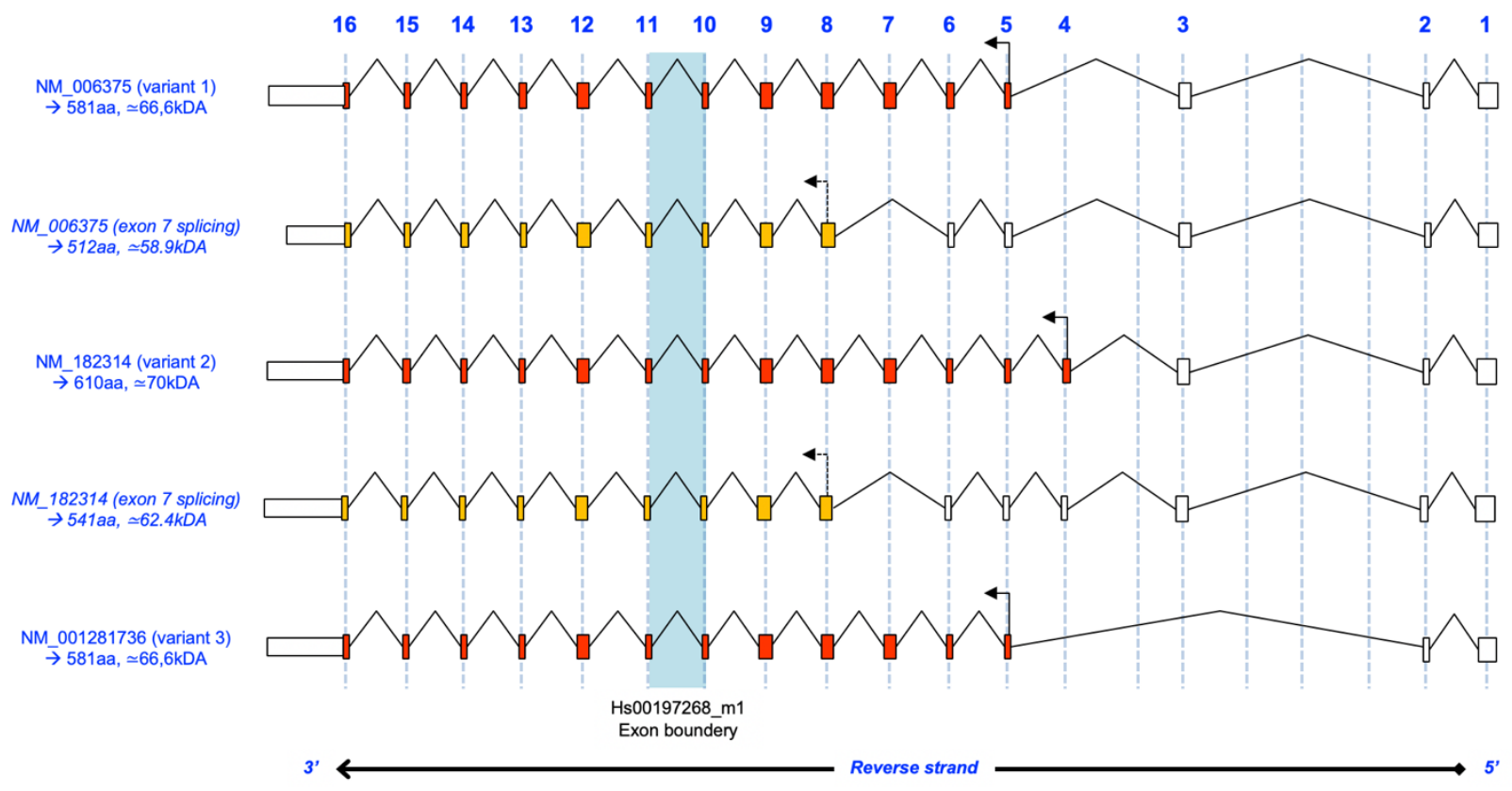

Data came from REFSEQ mRNAs (NM_182314 taken as reference for exon numbering). The blue bar represents exon 10-11 boundaries for qRT-PCR experiments using ENOX2 TaqMan predeveloped assay reagent (Hs00197268_m1). Theoretical derived molecular weights of proteins translated from the open reading frame of the different mRNA isoforms are given as an indication. Exons in red and orange correspond to full-length cDNA and exons potentially translated in case of exon 7 skipping (alternative translation initiation sites), respectively. 
bioRxiv preprint doi: https://doi.org/10.1101/2021.01.23.427819; this version posted January 24, 2021. The copyright holder for this preprint (which was not certified by peer review) is the author/funder. All rights reserved. No reuse allowed without permission.

\section{S3 Fig: Amino-acid and nucleotide sequences of full-length ENOX2.}

\footnotetext{
tggccctctggtcacagaaggcctcattgagaatggaggggaatcaagcaagaaaagaaagagaacaaatactccttcagaaatgatgacagagctaagttcacagttgaggaccacaca

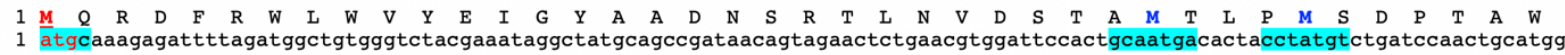

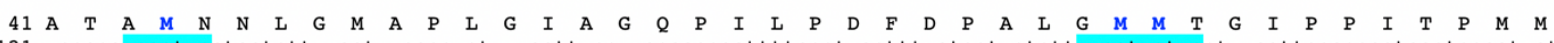
121 gccacagcaatgaataatcttggaatggcaccgctgggaattgccggacaaccaattttacctgactttgatcctgctcttggaatgatgactggaattccaccaataactccaatgatg

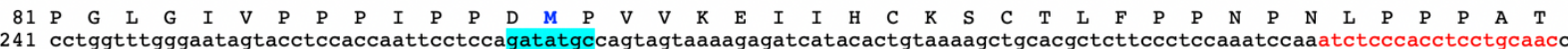

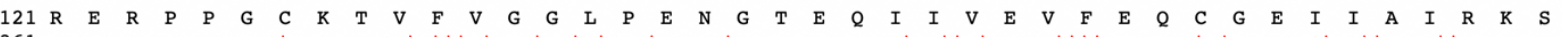
361 cgagaaagaccaccaggatgcaaaacagtatttgtgggtggtctgcctgaaaatgggacagagcaaatcattgtggaagttttcgagcagtgtggagagatcattgccattcgcaagagc

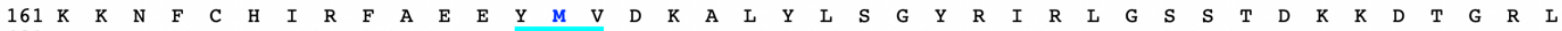
481 aagaagaacttctgccacattcgctttgctgaggagtacatggtggacaaagccetgtatctgtctggttaccgcattcgcctgggctctagtactgacaagaaggacacaggcagactc

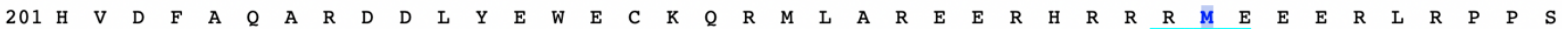
601 cacgttgatttcgcacaggctcgagatgacctgtatgagtgggagtgtaaacagcgtatgctagccagagaggagcgccatcgtagaagaatggaagaagaaagattgcgtccaccatct

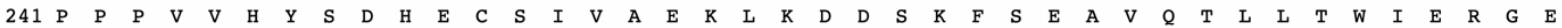
721 ccaccccagtggtccactattcagatcatgaatgcagcattgttgctgaaaaattaaaagatgattccaaattctcagaagctgtacagaccttgcttacctggatagagcgaggagag

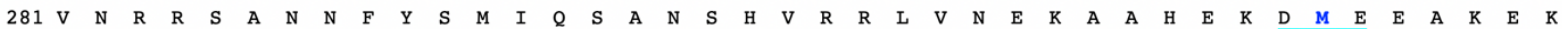
841 gtcaaccgtcgtagcgccaataacttctactccatgatccagtcggccaacagccatgtccgccgcctggtgaacgagaaagctgcccatgagaaagatatggaagaagcaaaggagaag

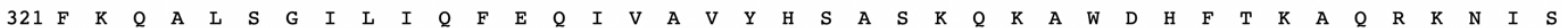
961 ttcaagcaggccctttctggaattctcattcaatttgagcagatagtggctgtgtaccattccgcctccaagcagaaggcatgggaccacttcacaaaagcccagcggaagaacatcagc

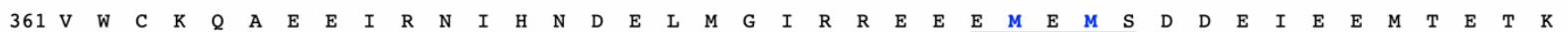
1081 gtgtggtgcaaacaagctgaggaaattcgcaacattcataatgatgaattaatgggaatcaggcgagaagaagaaatggaaatgtctgatgatgaaatagaagaaatgacagaaacaaaa

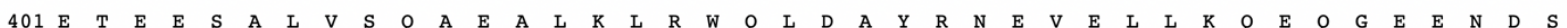
1201 gaaactgaggaatcagccttagtatcacaggcagaagctctgaaggaagaaaatgacagcetccgttggcagctcgatgcctaccggaatgaagtagaactgctcaagcaagaacaaggc

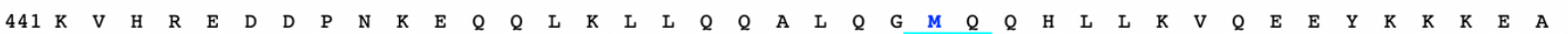
1321 aaagtccacagagaagatgaccctaacaaagaacagcagctgaaactcctgcaacaagccctgcaaggaatgcaacagcatctactcaaagtccaagaggaatacaaaaagaaagaagct

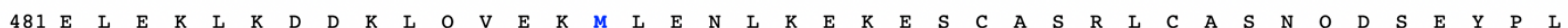
1441 gaacttgaaaaactcaaagatgacaagttacaggtggaaaaatgttggaaaatcttaaagaaaaggaaagctgtgcttctaggctgtgtgcctcaaaccaggatagcgaataccctctt

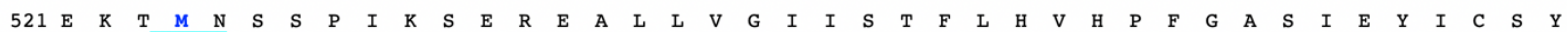
1561 gagaagaccatgaacagcagtcctatcaaatctgaacgtgaagcactgctagtggggattatctccacattccttcatgttcacccatttggagcaagcattgaatacatctgttccta

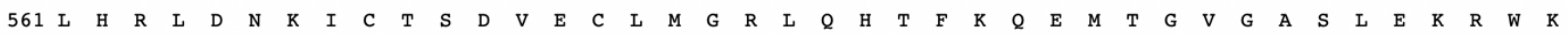
1681 ttgcaccgtcttgataataagatctgcaccagcgatgtggagtgtctcatgggtagactccagcataccttcaagcaggaaatgactggagttggagccagcctggaaaagagatggaaa

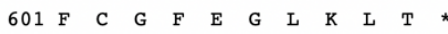
1801 ttctgtggcttcgagggcttgaagctgacctaa
}

Amino-acid and nucleotide numeration correspond to the theoretical protein of $610 \mathrm{aa}(70 \mathrm{kDa})$. The sequences underlined in blue indicate the most likely Kozak consensus for protein translation initiation. Sequences in red correspond to exon 7 (exon 4 in another nomenclature). In the case of exon 7 skipping (NM_183314 numbering), alternative translation initiation sites, such as the M231, initiate the production of various tumor-associated ENOX2 proteins of lower molecular weight. 
S4 Fig: Analysis of a potential relationship between ENOX2 protein levels and white blood cells (WBCs).

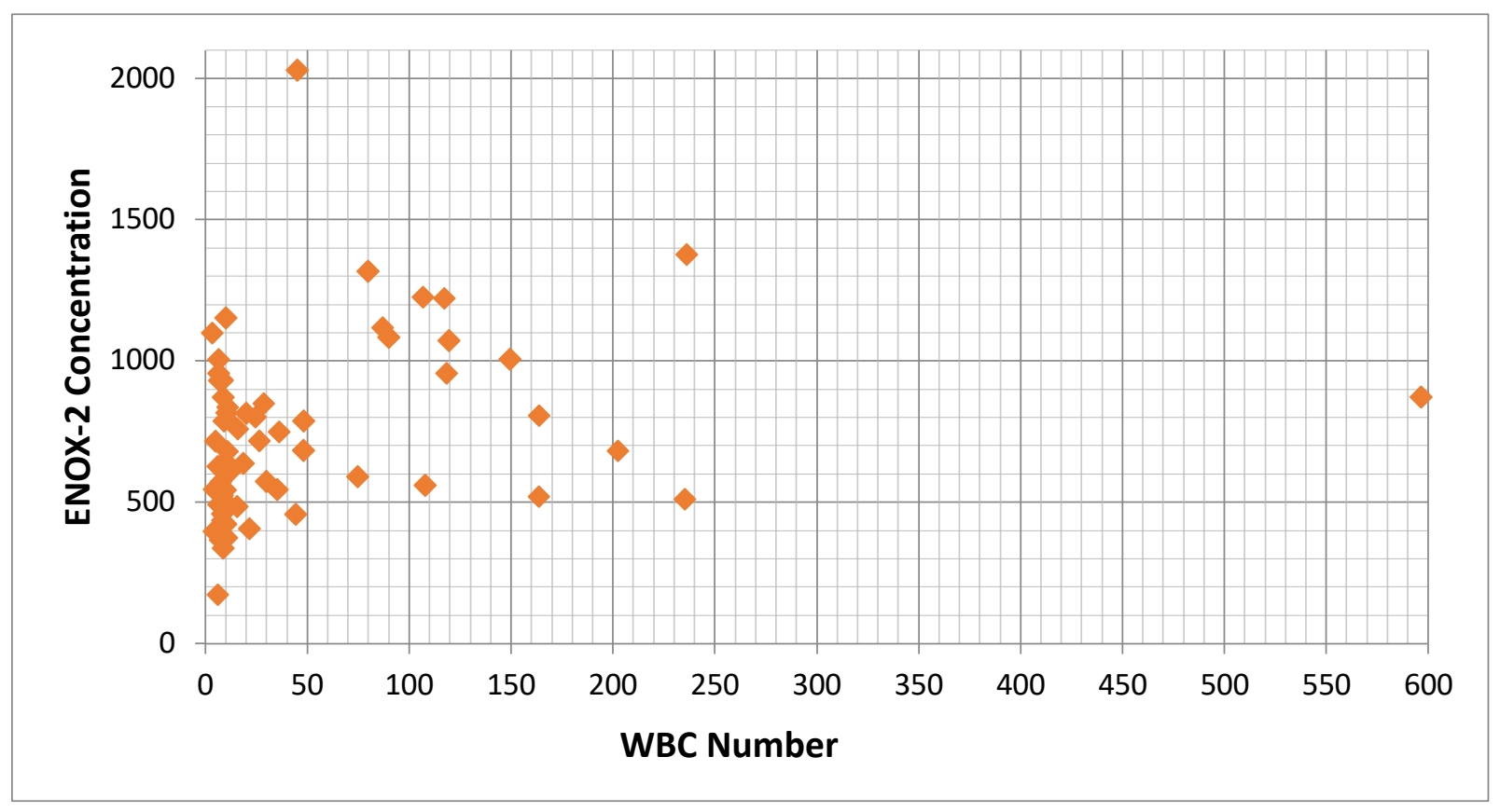

No correlation was observed between ENOX2 plasma concentrations and WBC count in CML patients at diagnosis. 
S5 Fig: Several potentially relevant protein-coding genes display a mRNA expression significantly correlated to ENOX2 mRNA expression.
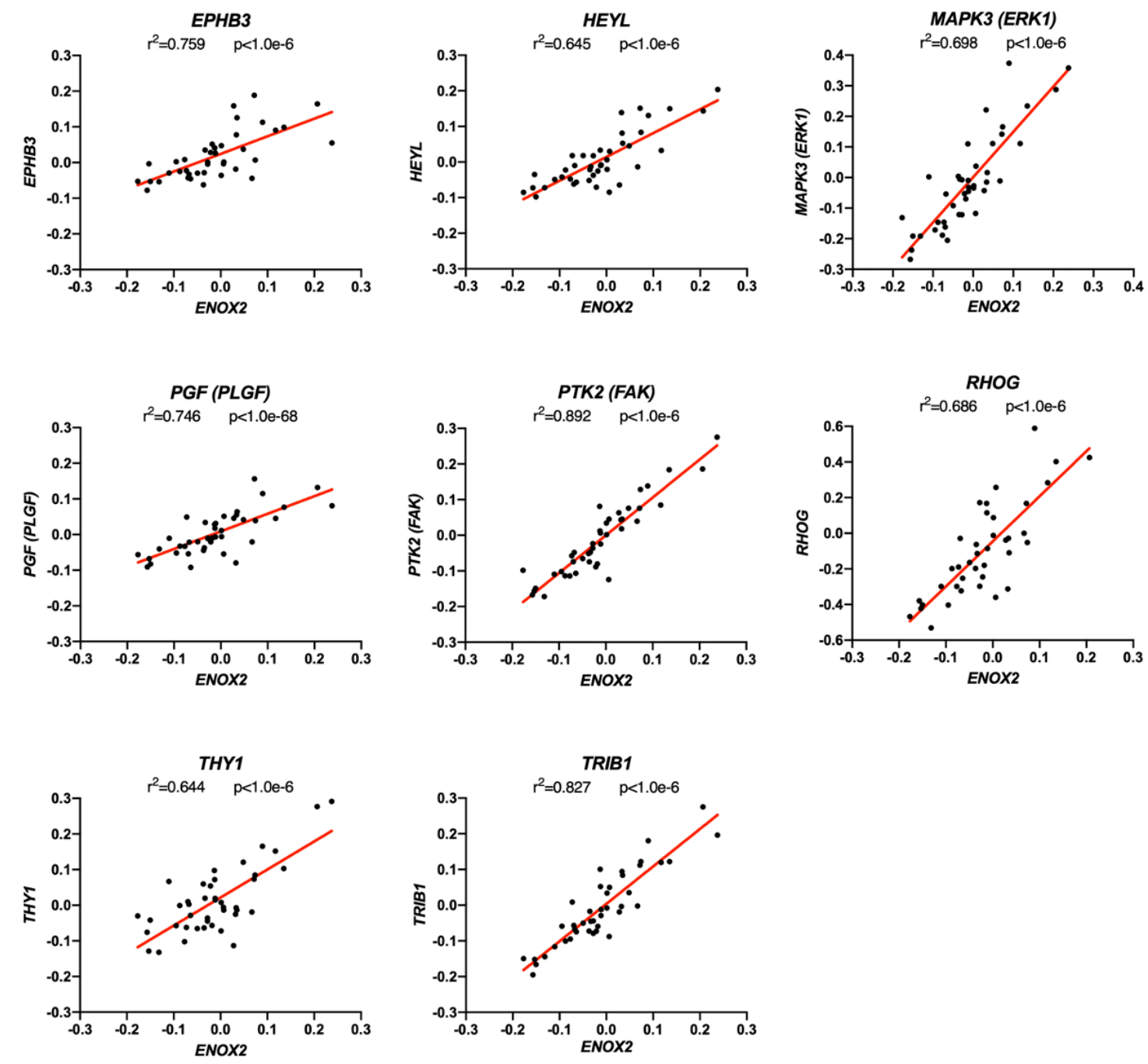

Linear regression reveals a high positive correlation degree between $E N O X 2$ and $E P H B 3, H E Y L$, ERK1, PlGF, FAK, RHOG, THY1, TRIB1 gene mRNA expression. The $\mathrm{r} 2$ and p parameters are shown on each graph. 
S1 Table: Patients characteristics (cohort ENOX2 mRNA expression).

\begin{tabular}{|c|c|c|c|c|c|c|c|c|}
\hline \multicolumn{3}{|r|}{ Patient } & \multicolumn{2}{|c|}{$\begin{array}{l}\text { Molecular follow-up } \\
\left(\% B C R-A B L 1 / A B L 1^{15}\right)\end{array}$} & \multicolumn{4}{|c|}{ TKI discontinuation } \\
\hline $\mathbf{N}^{\circ}$ & Sex & $\begin{array}{c}\text { Age at diagnosis } \\
\text { (years) }\end{array}$ & $\begin{array}{c}\text { Last test } \\
\text { (years following } \\
\text { diagnosis) }\end{array}$ & $\begin{array}{l}\text { Molecular } \\
\text { response }\end{array}$ & Yes/No & $\begin{array}{c}\text { Time to cessation } \\
\text { (years following } \\
\text { diagnosis) }\end{array}$ & Result & $\begin{array}{c}\text { Duration of TFS } \\
\text { (years) }\end{array}$ \\
\hline 1 & $\mathrm{M}$ & 55.2 & 11.9 & MR5 & Yes & 4.1 & TFS & 7.8 \\
\hline 2 & $\mathrm{M}$ & 60.1 & 3.0 & MR3 & No & & & \\
\hline 3 & $F$ & 45.2 & 12.6 & MR4.5 & Yes & 6.5 & TFS & 6.1 \\
\hline 4 & $\mathrm{M}$ & 76.2 & 7.9 & MR4.5 & No & & & \\
\hline 5 & $\mathrm{M}$ & 45.5 & 9.2 & MR4.5 & No & & & \\
\hline 6 & $\mathrm{~F}$ & 43.7 & 12.0 & MR5 & Yes & 5.6 & TFS & 6.4 \\
\hline 7 & $\mathrm{M}$ & 66.9 & 1.8 & MR3 & No & & & \\
\hline 8 & $\mathrm{M}$ & 56.5 & 14.6 & MR5 & Yes & 8.1 & TFS & 6.4 \\
\hline 9 & $\mathrm{~F}$ & 54.3 & 11.3 & MR5 & Yes & 5.7 & TFS & 5.6 \\
\hline 10 & $F$ & 48.6 & 11.1 & MR5 & No & & & \\
\hline 11 & $F$ & 60.4 & 15.0 & MR2 & No & & & \\
\hline 12 & $\mathrm{M}$ & 37.4 & 11.3 & MR5 & Yes & 4.1 & Recurrence & \\
\hline 13 & $M$ & 58.5 & 8.2 & MR4.5 & No & & & \\
\hline 14 & $\mathrm{M}$ & 64.2 & 15.4 & MR5 & No & & & \\
\hline 15 & $M$ & 60.5 & 15.3 & MR3 & Yes & 7.5 & Recurrence & \\
\hline 16 & $\mathrm{M}$ & 21.5 & 12.3 & MR4.5 & No & & & \\
\hline 17 & $F$ & 56.8 & 11.3 & MR5 & Yes & 8.0 & Recurrence & \\
\hline 18 & $\mathrm{M}$ & 71.0 & 15.4 & MR5 & Yes & 3.3 & Recurrence & \\
\hline 19 & $\mathrm{~F}$ & 34.9 & 17.4 & MR3 & No & & & \\
\hline 20 & $\mathrm{~F}$ & 84.8 & 7.5 & MR2 & Yes & 6.3 & Recurrence & \\
\hline 21 & $\mathrm{M}$ & 48.6 & 13.3 & MR4.5 & Yes & 7.9 & TFS & 5.3 \\
\hline 22 & $\mathrm{~F}$ & 57.9 & 5.6 & MR4.5 & No & & & \\
\hline 23 & $\mathrm{M}$ & 73.6 & 4.3 & MR3 & No & & & \\
\hline 24 & $\mathrm{M}$ & 69.6 & 4.4 & MR4.5 & No & & & \\
\hline 25 & $\mathrm{M}$ & 72.3 & 14.7 & MR5 & Yes & 4.5 & Recurrence & \\
\hline 26 & $\mathrm{M}$ & 64.8 & 11.6 & MR4 & No & & & \\
\hline 27 & $\mathrm{~F}$ & 45.7 & 13.1 & MR5 & Yes & 2.7 & TFS & 10.4 \\
\hline 28 & $\mathrm{M}$ & 58.8 & 9.0 & MR3 & No & & & \\
\hline 29 & $\mathrm{M}$ & 74.4 & 11.1 & MR4 & No & & & \\
\hline 30 & $\mathrm{M}$ & 56.8 & 6.4 & MR4.5 & Yes & 5.0 & Recurrence & \\
\hline 31 & $\mathrm{~F}$ & 40.3 & 13.7 & MR5 & No & & & \\
\hline
\end{tabular}




\begin{tabular}{|l|c|c|c|c|c|c|l|l|}
\hline 32 & $\mathrm{M}$ & 50.9 & 13.2 & MR4 & No & & & \\
\hline 33 & $\mathrm{M}$ & 83.8 & 4.9 & MR4.5 & No & & & \\
\hline 34 & $\mathrm{M}$ & 76.6 & 4.0 & MR4 & No & & & \\
\hline 35 & $\mathrm{M}$ & 59.3 & 17.0 & MR4 & Yes & 10.7 & Recurrence & \\
\hline 36 & $\mathrm{~F}$ & 84.4 & 2.9 & MR3 & No & & & \\
\hline
\end{tabular}

TKI, tyrosine kinase inhibitors; TFS, treatment free remission; Molecular recurrence (recurrence in the table) is defined by the loss of MMR (major molecular response) or MR3.

Molecular responses: MR2, $\% B C R-A B L 1 / A B L 1^{\mathrm{IS}}<1 \%$; MR3, $\% B C R-A B L 1 / A B L 1^{\mathrm{IS}}<0.1 \%$; MR4, \%BCR-ABL $1 / A B L 1^{\mathrm{IS}}<0.01 \%$; MR4.5, \%BCR-ABL1/ABLI $1^{\mathrm{IS}}<0.0032 \%$ (or 100000 copies $>A B L 1>32000$ copies if undetectable $B C R-A B L 1$ ); MR5, \%BCR-ABL1/ABL1 $1^{\mathrm{IS}}<0.001 \%$ (or $A B L 1>100000$ copies if undetectable $B C R-A B L 1$ ). 


\section{S2 Table: Genes correlated to ENOX2 mRNA expression.}

In red, genes known to be involved in essential cell processes.

to be

continued.

\begin{tabular}{|c|c|c|}
\hline Gene symbol & $R$ values & p Values \\
\hline ENOX2 & 1 & $<1.0 \mathrm{e}-6$ \\
\hline$R C V R N$ & 0.96617126 & $<1.0 \mathrm{e}-6$ \\
\hline MYH11 & 0.956953 & $<1.0 \mathrm{e}-6$ \\
\hline ANP32C & 0.9553184 & $<1.0 \mathrm{e}-6$ \\
\hline EFEMP1 & 0.9547916 & $<1.0 \mathrm{e}-6$ \\
\hline$K L H D C 8 A$ & 0.9460578 & $<1.0 \mathrm{e}-6$ \\
\hline PTK2 & 0.94451255 & $<1.0 \mathrm{e}-6$ \\
\hline$A P I P$ & 0.94312906 & $<1.0 \mathrm{e}-6$ \\
\hline POU3F4 & 0.9411655 & $<1.0 \mathrm{e}-6$ \\
\hline DISP1 & 0.94022304 & $<1.0 \mathrm{e}-6$ \\
\hline$S T 7 L$ & 0.936308 & $<1.0 \mathrm{e}-6$ \\
\hline FLJ32658 & 0.93621475 & $<1.0 \mathrm{e}-6$ \\
\hline$J A G 2$ & 0.9286973 & $<1.0 \mathrm{e}-6$ \\
\hline ADAM6 & 0.92834216 & $<1.0 \mathrm{e}-6$ \\
\hline$A B C F 3$ & 0.92229617 & $<1.0 \mathrm{e}-6$ \\
\hline SYT17 & 0.9192649 & $<1.0 \mathrm{e}-6$ \\
\hline C10orf10 & 0.91603184 & $<1.0 \mathrm{e}-6$ \\
\hline PCDHB6 & 0.913041 & $<1.0 \mathrm{e}-6$ \\
\hline MPZL2 & 0.9122278 & $<1.0 \mathrm{e}-6$ \\
\hline RPP14 & 0.9114203 & $<1.0 \mathrm{e}-6$ \\
\hline OTOF & 0.9107501 & $<1.0 \mathrm{e}-6$ \\
\hline NEUROG3 & 0.90937275 & $<1.0 \mathrm{e}-6$ \\
\hline$T R I B 1$ & 0.9091573 & $<1.0 \mathrm{e}-6$ \\
\hline VPS45 & 0.9077846 & $<1.0 \mathrm{e}-6$ \\
\hline NAGS & 0.9065467 & $<1.0 \mathrm{e}-6$ \\
\hline TNFRSF6B & 0.9064349 & $<1.0 \mathrm{e}-6$ \\
\hline TJP3 & 0.9064074 & $<1.0 \mathrm{e}-6$ \\
\hline$C P L X 2$ & 0.9041828 & $<1.0 \mathrm{e}-6$ \\
\hline$D M P K$ & 0.90411955 & $<1.0 \mathrm{e}-6$ \\
\hline$A P 1 M 1$ & 0.9030762 & $<1.0 \mathrm{e}-6$ \\
\hline KIAA1244 & 0.9018462 & $<1.0 \mathrm{e}-6$ \\
\hline UTF1 & 0.9012463 & $<1.0 \mathrm{e}-6$ \\
\hline NFATC4 & 0.90038896 & $<1.0 \mathrm{e}-6$ \\
\hline RGS7 & 0.899976 & $<1.0 \mathrm{e}-6$ \\
\hline$N R G N$ & 0.8981791 & $<1.0 \mathrm{e}-6$ \\
\hline
\end{tabular}

\begin{tabular}{|c|c|c|}
\hline Gene symbol & $R$ values & p Values \\
\hline C11orf30 & 0.88709366 & $<1.0 \mathrm{e}-6$ \\
\hline YIF1A & 0.8868629 & $<1.0 \mathrm{e}-6$ \\
\hline MAPK11 & 0.8868171 & $<1.0 \mathrm{e}-6$ \\
\hline APLNR & 0.8862749 & $<1.0 \mathrm{e}-6$ \\
\hline SSTR4 & 0.88561755 & $<1.0 \mathrm{e}-6$ \\
\hline PCIF1 & 0.88367957 & $<1.0 \mathrm{e}-6$ \\
\hline$O A Z 1$ & 0.88326156 & $<1.0 \mathrm{e}-6$ \\
\hline C10orf116 & 0.88301235 & $<1.0 \mathrm{e}-6$ \\
\hline APOA2 & 0.8816541 & $<1.0 \mathrm{e}-6$ \\
\hline CACYBP & 0.88127524 & $<1.0 \mathrm{e}-6$ \\
\hline PNMA3 & 0.8805079 & $<1.0 \mathrm{e}-6$ \\
\hline FRMPD1 & 0.8795783 & $<1.0 \mathrm{e}-6$ \\
\hline B4GALT7 & 0.8795142 & $<1.0 \mathrm{e}-6$ \\
\hline$R T B D N$ & 0.8791431 & $<1.0 \mathrm{e}-6$ \\
\hline CKAP2L & 0.87891597 & $<1.0 \mathrm{e}-6$ \\
\hline$B M P 7$ & 0.87850946 & $<1.0 \mathrm{e}-6$ \\
\hline$O D Z 1$ & 0.8784246 & $<1.0 \mathrm{e}-6$ \\
\hline PPP5C & 0.8771678 & $<1.0 \mathrm{e}-6$ \\
\hline ECEL1 & 0.8770625 & $<1.0 \mathrm{e}-6$ \\
\hline HOXC10 & 0.87696546 & $<1.0 \mathrm{e}-6$ \\
\hline CACNA1H & 0.8764651 & $<1.0 \mathrm{e}-6$ \\
\hline TACR2 & 0.8759702 & $<1.0 \mathrm{e}-6$ \\
\hline GTF3C1 & 0.8758702 & $<1.0 \mathrm{e}-6$ \\
\hline SLC7A8 & 0.8753778 & $<1.0 \mathrm{e}-6$ \\
\hline DHPS & 0.8748936 & $<1.0 \mathrm{e}-6$ \\
\hline MAGEA5 & 0.8733235 & $<1.0 \mathrm{e}-6$ \\
\hline TFAP2B & 0.8719522 & $<1.0 \mathrm{e}-6$ \\
\hline FAM65A & 0.87178475 & $<1.0 \mathrm{e}-6$ \\
\hline KRT8 & 0.87152994 & $<1.0 \mathrm{e}-6$ \\
\hline EPHB3 & 0.87142307 & $<1.0 \mathrm{e}-6$ \\
\hline REG3A & 0.87110436 & $<1.0 \mathrm{e}-6$ \\
\hline SFTPA1B & 0.8706763 & $<1.0 \mathrm{e}-6$ \\
\hline NOTUM & 0.86875397 & $<1.0 \mathrm{e}-6$ \\
\hline PITX3 & 0.86821973 & $<1.0 \mathrm{e}-6$ \\
\hline LYGG6C & 0.8674368 & $<1.0 \mathrm{e}-6$ \\
\hline
\end{tabular}




\begin{tabular}{|c|c|c|}
\hline PTPRS & 0.898072 & $<1.0 \mathrm{e}-6$ \\
\hline CRMP1 & 0.8973751 & $<1.0 \mathrm{e}-6$ \\
\hline ZNF107 & 0.89688665 & $<1.0 \mathrm{e}-6$ \\
\hline DTX3 & 0.8961144 & $<1.0 \mathrm{e}-6$ \\
\hline GPX7 & 0.8958358 & $<1.0 \mathrm{e}-6$ \\
\hline GRIA1 & 0.89445287 & $<1.0 \mathrm{e}-6$ \\
\hline PAK4 & 0.8937744 & $<1.0 \mathrm{e}-6$ \\
\hline LOC284701 & 0.8899431 & $<1.0 \mathrm{e}-6$ \\
\hline GPR17 & 0.8890001 & $<1.0 \mathrm{e}-6$ \\
\hline PRPH & 0.8873445 & $<1.0 \mathrm{e}-6$ \\
\hline
\end{tabular}

\begin{tabular}{|c|c|c|} 
ATN1 & 0.8672403 & $<1.0 \mathrm{e}-6$ \\
\hline GGT1 & 0.8672297 & $<1.0 \mathrm{e}-6$ \\
\hline SLC2A4 & 0.8656502 & $<1.0 \mathrm{e}-6$ \\
\hline CLDN4 & 0.8652593 & $<1.0 \mathrm{e}-6$ \\
\hline TPM2 & 0.86410105 & $<1.0 \mathrm{e}-6$ \\
\hline CRAT & 0.8638945 & $<1.0 \mathrm{e}-6$ \\
\hline PGF & 0.86375177 & $<1.0 \mathrm{e}-6$ \\
\hline PLXDC1 & 0.8631661 & $<1.0 \mathrm{e}-6$ \\
\hline DIS3 & 0.862996 & $<1.0 \mathrm{e}-6$ \\
\hline ATP1B2 & 0.8626277 & $<1.0 \mathrm{e}-6$ \\
\hline
\end{tabular}

S2 Table: Genes correlated to ENOX2 mRNA expression.

continued.

\begin{tabular}{|c|c|c|}
\hline Gene symbol & R values & p Values \\
\hline FOXE1 & 0.86260194 & $<1.0 \mathrm{e}-6$ \\
\hline PEMT & 0.8624352 & $<1.0 \mathrm{e}-6$ \\
\hline FBXL8 & 0.8623713 & $<1.0 \mathrm{e}-6$ \\
\hline TFF2 & 0.8621231 & $<1.0 \mathrm{e}-6$ \\
\hline PTCD1 & 0.86208713 & $<1.0 \mathrm{e}-6$ \\
\hline SLC29A3 & 0.86157095 & $<1.0 \mathrm{e}-6$ \\
\hline CHRNB2 & 0.8613419 & $<1.0 \mathrm{e}-6$ \\
\hline WFDC2 & 0.8609538 & $<1.0 \mathrm{e}-6$ \\
\hline B4GALNT1 & 0.8607964 & $<1.0 \mathrm{e}-6$ \\
\hline ATAD4 & 0.8601189 & $<1.0 \mathrm{e}-6$ \\
\hline PLK1 & 0.85977006 & $<1.0 \mathrm{e}-6$ \\
\hline MSLN & 0.8595884 & $<1.0 \mathrm{e}-6$ \\
\hline EPHA1 & 0.8593882 & $<1.0 \mathrm{e}-6$ \\
\hline PAX8 & 0.859387 & $<1.0 \mathrm{e}-6$ \\
\hline MTA2 & 0.8590291 & $<1.0 \mathrm{e}-6$ \\
\hline FLI4968 & 0.8589778 & $<1.0 \mathrm{e}-6$ \\
\hline TTLL6 & 0.8582699 & $<1.0 \mathrm{e}-6$ \\
\hline KRT31 & 0.8579513 & $<1.0 \mathrm{e}-6$ \\
\hline SLC6A12 & 0.8573194 & $<1.0 \mathrm{e}-6$ \\
\hline MSI1 & 0.8559213 & $<1.0 \mathrm{e}-6$ \\
\hline ACVR1B & 0.85500836 & $<1.0 \mathrm{e}-6$ \\
\hline MYL6 & 0.8547956 & $<1.0 \mathrm{e}-6$ \\
\hline LRRC28 & 0.85479534 & $<1.0 \mathrm{e}-6$ \\
\hline DEXI & 0.8547377 & $<1.0 \mathrm{e}-6$ \\
\hline G6PC & 0.8529736 & $<1.0 \mathrm{e}-6$ \\
\hline
\end{tabular}

\begin{tabular}{|c|c|c|}
\hline Gene symbol & R values & $\mathbf{p ~ V a l u e s}$ \\
\hline NR5A1 & 0.8442461 & $<1.0 \mathrm{e}-6$ \\
\hline B3GALT4 & 0.843811 & $<1.0 \mathrm{e}-6$ \\
\hline PCDHGC5 & 0.8437889 & $<1.0 \mathrm{e}-6$ \\
\hline PDZD4 & 0.84360224 & $<1.0 \mathrm{e}-6$ \\
\hline RIN3 & 0.8435184 & $<1.0 \mathrm{e}-6$ \\
\hline WNK4 & 0.8434865 & $<1.0 \mathrm{e}-6$ \\
\hline FBLN1 & 0.84334964 & $<1.0 \mathrm{e}-6$ \\
\hline ALPP & 0.8427555 & $<1.0 \mathrm{e}-6$ \\
\hline KCNN1 & 0.842419 & $<1.0 \mathrm{e}-6$ \\
\hline$P T P R U$ & 0.8424166 & $<1.0 \mathrm{e}-6$ \\
\hline DKFZP434I0714 & 0.84233415 & $<1.0 \mathrm{e}-6$ \\
\hline LMX1B & 0.84229946 & $<1.0 \mathrm{e}-6$ \\
\hline OPTC & 0.8420299 & $<1.0 \mathrm{e}-6$ \\
\hline FIBCD1 & 0.8418452 & $<1.0 \mathrm{e}-6$ \\
\hline FL46321 & 0.84169245 & $<1.0 \mathrm{e}-6$ \\
\hline RENBP & 0.8415789 & $<1.0 \mathrm{e}-6$ \\
\hline CLPTM1 & 0.8406547 & $<1.0 \mathrm{e}-6$ \\
\hline$A T X N 80 S$ & 0.8405387 & $<1.0 \mathrm{e}-6$ \\
\hline MAZ & 0.840483 & $<1.0 \mathrm{e}-6$ \\
\hline AGRN & 0.8401711 & $<1.0 \mathrm{e}-6$ \\
\hline PYCR2 & 0.8400439 & $<1.0 \mathrm{e}-6$ \\
\hline MTP18 & 0.8400094 & $<1.0 \mathrm{e}-6$ \\
\hline SCN2B & 0.8394415 & $<1.0 \mathrm{e}-6$ \\
\hline C1Orf172 & 0.83909196 & $<1.0 \mathrm{e}-6$ \\
\hline KRT8P12 $61.0 \mathrm{e}-6$ \\
\hline
\end{tabular}




\begin{tabular}{|c|c|c|}
\hline STARD3 & 0.8520861 & $<1.0 \mathrm{e}-6$ \\
\hline TGM4 & 0.85199827 & $<1.0 \mathrm{e}-6$ \\
\hline C19orf19 & 0.8512535 & $<1.0 \mathrm{e}-6$ \\
\hline PRSS16 & 0.8508587 & $<1.0 \mathrm{e}-6$ \\
\hline GPX5 & 0.85071474 & $<1.0 \mathrm{e}-6$ \\
\hline DRD2 & 0.8501521 & $<1.0 \mathrm{e}-6$ \\
\hline CALY & 0.84971577 & $<1.0 \mathrm{e}-6$ \\
\hline UGT1A1 & 0.848902 & $<1.0 \mathrm{e}-6$ \\
\hline PLEKHA4 & 0.8486737 & $<1.0 \mathrm{e}-6$ \\
\hline EHD2 & 0.84846425 & $<1.0 \mathrm{e}-6$ \\
\hline CCNJL & 0.848365 & $<1.0 \mathrm{e}-6$ \\
\hline C1Orf189 & 0.8483349 & $<1.0 \mathrm{e}-6$ \\
\hline CD22 & 0.84821826 & $<1.0 \mathrm{e}-6$ \\
\hline CYP2D6 & 0.84755015 & $<1.0 \mathrm{e}-6$ \\
\hline CPAMD8 & 0.8473105 & $<1.0 \mathrm{e}-6$ \\
\hline VPS4B & 0.8468782 & $<1.0 \mathrm{e}-6$ \\
\hline MLH3 & 0.8464334 & $<1.0 \mathrm{e}-6$ \\
\hline MAP1S & 0.84611046 & $<1.0 \mathrm{e}-6$ \\
\hline MMP17 & 0.84597486 & $<1.0 \mathrm{e}-6$ \\
\hline GNAO1 & 0.8455387 & $<1.0 \mathrm{e}-6$ \\
\hline PPP2R4 & 0.84523815 & $<1.0 \mathrm{e}-6$ \\
\hline ADAM11 6 & 0.8447383 & $<1.0 \mathrm{e}-6$ \\
\hline
\end{tabular}

\begin{tabular}{|c|c|c|}
\hline$Z Y X$ & 0.83781403 & $<1.0 \mathrm{e}-6$ \\
\hline REG1B & 0.8373963 & $<1.0 \mathrm{e}-6$ \\
\hline PCDHGC4 & 0.83730096 & $<1.0 \mathrm{e}-6$ \\
\hline CST2 & 0.83702946 & $<1.0 \mathrm{e}-6$ \\
\hline RAPSN & 0.8365893 & $<1.0 \mathrm{e}-6$ \\
\hline COL4A1 & 0.8365255 & $<1.0 \mathrm{e}-6$ \\
\hline KIR2DL3 & 0.8361879 & $<1.0 \mathrm{e}-6$ \\
\hline CRTC1 & 0.8360285 & $<1.0 \mathrm{e}-6$ \\
\hline RNF26 & 0.83564883 & $<1.0 \mathrm{e}-6$ \\
\hline C11orf68 & 0.835429 & $<1.0 \mathrm{e}-6$ \\
\hline$A D R A 2 A$ & 0.83541036 & $<1.0 \mathrm{e}-6$ \\
\hline RFX1 & 0.83540446 & $<1.0 \mathrm{e}-6$ \\
\hline МАРКЗ & 0.8353626 & $<1.0 \mathrm{e}-6$ \\
\hline OR1F1 & 0.83532614 & $<1.0 \mathrm{e}-6$ \\
\hline ITIH4 & 0.834977 & $<1.0 \mathrm{e}-6$ \\
\hline LOC100127937 & 0.8348357 & $<1.0 \mathrm{e}-6$ \\
\hline KCNJ11 & 0.83476764 & $<1.0 \mathrm{e}-6$ \\
\hline IGSF8 & 0.8346403 & $<1.0 \mathrm{e}-6$ \\
\hline$A P 1 M 2$ & 0.83272463 & $<1.0 \mathrm{e}-6$ \\
\hline ZIM2 & 0.83234274 & $<1.0 \mathrm{e}-6$ \\
\hline C14orf129 & 0.8323396 & $<1.0 \mathrm{e}-6$ \\
\hline TAAR5 & 0.8322871 & $<1.0 \mathrm{e}-6$ \\
\hline
\end{tabular}

S2 Table: Genes correlated to ENOX2 mRNA expression.

\begin{tabular}{|c|c|c|}
\hline Gene symbol & R values & $\mathbf{p}$ Values \\
\hline XPNPEP3 & 0.8322395 & $<1.0 \mathrm{e}-6$ \\
\hline C8orf73 & 0.8317661 & $<1.0 \mathrm{e}-6$ \\
\hline RNF151 & 0.8317153 & $<1.0 \mathrm{e}-6$ \\
\hline COL16A1 & 0.8315634 & $<1.0 \mathrm{e}-6$ \\
\hline SYDE1 & 0.83143365 & $<1.0 \mathrm{e}-6$ \\
\hline KIFC3 & 0.83120286 & $<1.0 \mathrm{e}-6$ \\
\hline HDAC10 & 0.8310805 & $<1.0 \mathrm{e}-6$ \\
\hline ZFR & 0.830925 & $<1.0 \mathrm{e}-6$ \\
\hline CNOT3 & 0.8305889 & $<1.0 \mathrm{e}-6$ \\
\hline COPE & 0.8305486 & $<1.0 \mathrm{e}-6$ \\
\hline TNFRSF12A & 0.83052605 & $<1.0 \mathrm{e}-6$ \\
\hline MCOLN1 & 0.8302164 & $<1.0 \mathrm{e}-6$ \\
\hline SHISA5 & 0.8302118 & $<1.0 \mathrm{e}-6$ \\
\hline
\end{tabular}

\begin{tabular}{|c|c|c|}
\hline Gene symbol & R values & p Values \\
\hline SLC4A2 & 0.821128 & $<1.0 \mathrm{e}-6$ \\
\hline$E C E 2$ & 0.8203133 & $<1.0 \mathrm{e}-6$ \\
\hline ADAM33 & 0.8196176 & $<1.0 \mathrm{e}-6$ \\
\hline RCN3 & 0.8193855 & $<1.0 \mathrm{e}-6$ \\
\hline C8orf4 & 0.81904936 & $<1.0 \mathrm{e}-6$ \\
\hline GARNL1 & 0.8188982 & $<1.0 \mathrm{e}-6$ \\
\hline$P T M S$ & 0.8184042 & $<1.0 \mathrm{e}-6$ \\
\hline CARM1 & 0.81809825 & $<1.0 \mathrm{e}-6$ \\
\hline RGL1 & 0.8180456 & $<1.0 \mathrm{e}-6$ \\
\hline$P N M A L 2$ & 0.8178215 & $<1.0 \mathrm{e}-6$ \\
\hline$D Y N C 2 L I 1$ & 0.8177664 & $<1.0 \mathrm{e}-6$ \\
\hline LDB1 & 0.8173905 & $<1.0 \mathrm{e}-6$ \\
\hline SDS & 0.81736207 & $<1.0 \mathrm{e}-6$ \\
\hline
\end{tabular}




\begin{tabular}{|c|c|c|}
\hline RGS20 & 0.8301142 & $<1.0$ e- 6 \\
\hline LOC100129850 & 0.82973224 & $<1.0 \mathrm{e}-6$ \\
\hline GLTSCR1 & 0.82956636 & $<1.0$ e- 6 \\
\hline VSTM2L & 0.8294069 & $<1.0 \mathrm{e}-6$ \\
\hline SATB1 & 0.8293123 & $<1.0 \mathrm{e}-6$ \\
\hline SPRR2D & 0.82926977 & $<1.0 \mathrm{e}-6$ \\
\hline CYP11B1 & 0.8287602 & $<1.0 \mathrm{e}-6$ \\
\hline SGTA & 0.8287286 & $<1.0 \mathrm{e}-6$ \\
\hline$S P R R 1 B$ & 0.82871044 & $<1.0 \mathrm{e}-6$ \\
\hline$S N C B$ & 0.8284577 & $<1.0 \mathrm{e}-6$ \\
\hline APLN & 0.8283668 & $<1.0 \mathrm{e}-6$ \\
\hline$S P R R 2 A$ & 0.8283278 & $<1.0 \mathrm{e}-6$ \\
\hline RHOG & 0.82828736 & $<1.0 \mathrm{e}-6$ \\
\hline CHAC1 & 0.82824093 & $<1.0 \mathrm{e}-6$ \\
\hline TTC22 & 0.8280334 & $<1.0 \mathrm{e}-6$ \\
\hline RNF128 & 0.82753456 & $<1.0 \mathrm{e}-6$ \\
\hline SNX26 & 0.82713646 & $<1.0 \mathrm{e}-6$ \\
\hline KIAA1754L & 0.82613075 & $<1.0 \mathrm{e}-6$ \\
\hline KIAA1529 & 0.82609916 & $<1.0 \mathrm{e}-6$ \\
\hline$R / C 8 B$ & 0.825819 & $<1.0 \mathrm{e}-6$ \\
\hline GNAT1 & 0.8257777 & $<1.0 \mathrm{e}-6$ \\
\hline SFTPB & 0.8254168 & $<1.0 \mathrm{e}-6$ \\
\hline CACNA1F & 0.8245132 & $<1.0 \mathrm{e}-6$ \\
\hline PI15 & 0.82392 & $<1.0 \mathrm{e}-6$ \\
\hline MEGF6 & 0.8238893 & $<1.0 \mathrm{e}-6$ \\
\hline$A N K D D 1 A$ & 0.8237899 & $<1.0 \mathrm{e}-6$ \\
\hline ITGBLI & 0.8236786 & $<1.0 \mathrm{e}-6$ \\
\hline PDK2 & 0.8232525 & $<1.0 \mathrm{e}-6$ \\
\hline LMBR1L & 0.8232194 & $<1.0 \mathrm{e}-6$ \\
\hline FTCD & 0.82304573 & $<1.0 \mathrm{e}-6$ \\
\hline$A D R M 1$ & 0.822709 & $<1.0 \mathrm{e}-6$ \\
\hline$A R S A$ & 0.8220143 & $<1.0 \mathrm{e}-6$ \\
\hline CYP4A11 & 0.82194686 & $<1.0 \mathrm{e}-6$ \\
\hline$I K B K G$ & 0.8217774 & $<1.0 \mathrm{e}-6$ \\
\hline
\end{tabular}

\begin{tabular}{|c|c|c|}
\hline RBM4 & 0.8173064 & $<1.0 \mathrm{e}-6$ \\
\hline WBSCR17 & 0.8171683 & $<1.0 \mathrm{e}-6$ \\
\hline$T N N$ & 0.81709546 & $<1.0 \mathrm{e}-6$ \\
\hline ACTN4 & 0.8161465 & $<1.0 \mathrm{e}-6$ \\
\hline TUB & 0.8161079 & $<1.0 \mathrm{e}-6$ \\
\hline H1FNT & 0.81576854 & $<1.0 \mathrm{e}-6$ \\
\hline CSF2RB & 0.815587 & $<1.0 \mathrm{e}-6$ \\
\hline $\mathrm{CDH} 23$ & 0.8152525 & $<1.0 \mathrm{e}-6$ \\
\hline EIF3K & 0.81524795 & $<1.0 \mathrm{e}-6$ \\
\hline GMEB2 & 0.81287766 & $<1.0 \mathrm{e}-6$ \\
\hline ELFN2 & 0.81287444 & $<1.0 \mathrm{e}-6$ \\
\hline C14orf172 & 0.812803 & $<1.0 \mathrm{e}-6$ \\
\hline$B C L 2 L 2$ & 0.8126579 & $<1.0 \mathrm{e}-6$ \\
\hline DNAJA2 & 0.81254673 & $<1.0 \mathrm{e}-6$ \\
\hline$D L K 1$ & 0.8124666 & $<1.0 \mathrm{e}-6$ \\
\hline ADAM29 & 0.8123947 & $<1.0 \mathrm{e}-6$ \\
\hline MAPK8IP2 & 0.8121275 & $<1.0 \mathrm{e}-6$ \\
\hline FOSL2 & 0.81212395 & $<1.0 \mathrm{e}-6$ \\
\hline RAC2 & 0.8118523 & $<1.0 \mathrm{e}-6$ \\
\hline EPB41 & 0.81175447 & $<1.0 \mathrm{e}-6$ \\
\hline NINJ1 & 0.81159925 & $<1.0 \mathrm{e}-6$ \\
\hline LOC150837 & 0.8113656 & $<1.0 \mathrm{e}-6$ \\
\hline ZDHHC1 & 0.8102412 & $<1.0 \mathrm{e}-6$ \\
\hline ATP1B4 & 0.8100232 & $<1.0 \mathrm{e}-6$ \\
\hline GHSR & 0.8099814 & $<1.0 \mathrm{e}-6$ \\
\hline IL22RA1 & 0.80987364 & $<1.0 \mathrm{e}-6$ \\
\hline CABIN1 & 0.80941373 & $<1.0 \mathrm{e}-6$ \\
\hline NPBWR2 & 0.8083389 & $<1.0 \mathrm{e}-6$ \\
\hline REG1A & 0.8082004 & $<1.0 \mathrm{e}-6$ \\
\hline CACNA1A & 0.8077839 & $<1.0 \mathrm{e}-6$ \\
\hline SLC3OA3 & 0.80736727 & $<1.0 \mathrm{e}-6$ \\
\hline MCF2L & 0.8068927 & $<1.0 \mathrm{e}-6$ \\
\hline TCL6 & 0.80667216 & $<1.0 \mathrm{e}-6$ \\
\hline METTL1O & 0.8066095 & $<1.0 \mathrm{e}-6$ \\
\hline
\end{tabular}




\section{S2 Table: Genes correlated with ENOX2 mRNA expression.}

\begin{tabular}{|c|c|c|}
\hline Gene symbol & R values & p Values \\
\hline SMAD5OS & 0.8059775 & $<1.0 \mathrm{e}-6$ \\
\hline TC2CD2L & 0.8056723 & $<1.0 \mathrm{e}-6$ \\
\hline RRAS & 0.8054051 & $<1.0 \mathrm{e}-6$ \\
\hline UPB1 & 0.8044197 & $<1.0 \mathrm{e}-6$ \\
\hline NPAS1 & 0.80421555 & $<1.0 \mathrm{e}-6$ \\
\hline C9Orf114 & 0.8039769 & $<1.0 \mathrm{e}-6$ \\
\hline RUSC2 & 0.80360794 & $<1.0 \mathrm{e}-6$ \\
\hline FASTK & 0.8034226 & $<1.0 \mathrm{e}-6$ \\
\hline HEYL & 0.8029919 & $<1.0 \mathrm{e}-6$ \\
\hline SMR3A & 0.8029302 & $<1.0 \mathrm{e}-6$ \\
\hline THY1 & 0.80260617 & $<1.0 \mathrm{e}-6$ \\
\hline IGHMBP2 & 0.80242604 & $<1.0 \mathrm{e}-6$ \\
\hline GCK & 0.80231726 & $<1.0 \mathrm{e}-6$ \\
\hline HARS & 0.80198824 & $<1.0 \mathrm{e}-6$ \\
\hline ZMIZ2 & 0.8013899 & $<1.0 \mathrm{e}-6$ \\
\hline AP2A2 & 0.80138415 & $<1.0 \mathrm{e}-6$ \\
\hline KCNAB2 & 0.8012798 & $<1.0 \mathrm{e}-6$ \\
\hline C1QL1 & 0.80122924 & $<1.0 \mathrm{e}-6$ \\
\hline VAPB & 0.80119395 & $<1.0 \mathrm{e}-6$ \\
\hline KIAA1688 & 0.80085427 & $<1.0 \mathrm{e}-6$ \\
\hline$A V P R 2$ & 0.800773 & $<1.0 \mathrm{e}-6$ \\
\hline PSG4 & 0.8007616 & $<1.0 \mathrm{e}-6$ \\
\hline LOC4O0236 & 0.800309 & $<1.0 \mathrm{e}-6$ \\
\hline MVD & 0.8002809 & $<1.0 \mathrm{e}-6$ \\
\hline
\end{tabular}




\section{S3 Table: Proteins of ENOX2 potential network involved in critical biological processes.}

\begin{tabular}{|c|c|c|c|}
\hline $\begin{array}{l}\text { Protein } \\
\text { symbol }\end{array}$ & Complete name & Molecular function & Biological process \\
\hline ADAM11 & ADAM Metallopeptidase Domain 11 & Metallopeptidase activity & Protein metabolism \\
\hline ADAM33 & ADAM Metallopeptidase Domain 33 & Metallopeptidase activity & Protein metabolism \\
\hline ADRA2A & Alpha $2 \mathrm{~A}$ adrenergic receptor & G-protein coupled receptor activity & Cell communication ; Signal transduction \\
\hline APLN & Apelin & Receptor binding & Cell communication ; Signal transduction \\
\hline AVPR2 & Arginine vasopressin receptor 2 & $\begin{array}{l}\text { G-protein coupled receptor activity } \\
\text { Cell communication ; Signal } \\
\text { transduction }\end{array}$ & Cell communication ; Signal transduction \\
\hline BMP7 & Bone morphogenetic protein 7 & Receptor binding & Cell communication ; Signal transduction \\
\hline CARM1 & $\begin{array}{l}\text { Coactivator associated arginine } \\
\text { methlytransferase } 1\end{array}$ & Methyltransferase activity & Metabolism ; Energy pathways \\
\hline CHRNB2 & $\begin{array}{c}\text { Cholinergic receptor, neuronal nicotinic, beta } \\
\text { polypeptide } 2\end{array}$ & $\begin{array}{l}\text { Extracellular ligand-gated ion } \\
\text { channel activity }\end{array}$ & Transport \\
\hline COL16A1 & Collagen, type XVI, alpha 1 & $\begin{array}{l}\text { Extracellular matrix structural } \\
\text { constituent }\end{array}$ & Cell growth and/or maintenance \\
\hline COL4A1 & Collagen, type IV, alpha 1 & $\begin{array}{l}\text { Extracellular matrix structural } \\
\text { constituent }\end{array}$ & Cell growth and/or maintenance \\
\hline CYP11B1 & $\begin{array}{c}\text { Cytochrome P450, subfamily XIB, } \\
\text { polypeptide } 1\end{array}$ & Catalytic activity & Metabolism ; Energy pathways \\
\hline DHPS & Deoxyhypusine synthase & Transferase activity & Metabolism ; Energy pathways \\
\hline $\begin{array}{l}\text { DNAJA2 } \\
\text { (HIRIP4) }\end{array}$ & $\begin{array}{l}\text { DnaJ Heat Shock Protein Family (Hsp40) } \\
\qquad \text { Member A2 } \\
\text { (HIRA interacting protein 4) }\end{array}$ & Chaperone activity & Protein metabolism \\
\hline DRD2 & Dopamine receptor D2 & G-protein coupled receptor activity & Cell communication ; Signal transduction \\
\hline DTX3 & Deltex 3 & Ubiquitin-specific protease activity & Protein metabolism \\
\hline EPHA1 & EPH Receptor A1 & $\begin{array}{c}\text { Transmembrane receptor protein } \\
\text { tyrosine kinase activity }\end{array}$ & Cell communication ; Signal transduction \\
\hline EPHB3 & EPH Receptor B3 & $\begin{array}{c}\text { Transmembrane receptor protein } \\
\text { tyrosine kinase activity }\end{array}$ & Cell communication ; Signal transduction \\
\hline $\begin{array}{l}\text { FOSL2 } \\
\text { (FRA2) }\end{array}$ & $\begin{array}{l}\text { AP-1 Transcription Factor Subunit } \\
\text { (Fos-Related Antigen 2) }\end{array}$ & Transcription factor activity & $\begin{array}{l}\text { Regulation of nucleobase, nucleoside, nucleotide } \\
\text { and nucleic acid metabolism }\end{array}$ \\
\hline G6PC & Glucose-6-phosphatase & Hydrolase activity & Metabolism ; Energy pathways \\
\hline GCK & Glucokinase & Phosphorylase activity & Metabolism ; Energy pathways \\
\hline HEYL & $\begin{array}{l}\text { Hairy/enhancer-of-split related } \\
\text { with YRPW motif-like }\end{array}$ & Transcription regulator activity & $\begin{array}{c}\text { Regulation of nucleobase, nucleoside, nucleotide } \\
\text { and nucleic acid metabolism }\end{array}$ \\
\hline HOXC10 & Homeobox C10 & Transcription factor activity & $\begin{array}{c}\text { Regulation of nucleobase, nucleoside, nucleotide } \\
\text { and nucleic acid metabolism }\end{array}$ \\
\hline
\end{tabular}


bioRxiv preprint doi: https://doi.org/10.1101/2021.01.23.427819; this version posted January 24, 2021. The copyright holder for this preprint (which was not certified by peer review) is the author/funder. All rights reserved. No reuse allowed without permission.

\begin{tabular}{|c|c|c|c|} 
IKBKG & $\begin{array}{c}\text { Inhibitor of kappa light polypeptide gene } \\
\text { enhancer in B-cells, kinase gamma }\end{array}$ & $\begin{array}{c}\text { Receptor signaling complex scaffold } \\
\text { activity }\end{array}$ & Cell communication; Signal transduction \\
\hline ITGBL1 & Integrin beta like 1 & Cell adhesion molecule activity & Biological_process unknown \\
\hline JAG2 & Jagged 2 & Receptor binding & Cell communication; Signal transduction \\
\hline
\end{tabular}




\section{S3 Table: Proteins of ENOX2 potential network involved in critical biological processes.}

\begin{tabular}{|c|c|c|c|}
\hline $\begin{array}{l}\text { Protein } \\
\text { symbol }\end{array}$ & Complete name & Molecular function & Biological process \\
\hline MAPK11 & Mitogen-Activated Protein Kinase 11 & $\begin{array}{l}\text { Protein serine/threonine kinase } \\
\text { activity }\end{array}$ & Cell communication ; Signal transduction \\
\hline $\begin{array}{l}\text { MAPK3 } \\
\text { (ERK1) }\end{array}$ & $\begin{array}{l}\text { Mitogen-Activated Protein Kinase } 3 \\
\text { (Extracellular signal-regulated kinase 1) }\end{array}$ & $\begin{array}{l}\text { Protein serine/threonine kinase } \\
\text { activity }\end{array}$ & Cell communication ; Signal transduction \\
\hline $\begin{array}{l}\text { MAPK8IP2 } \\
\text { (JIP2) }\end{array}$ & $\begin{array}{l}\text { Mitogen-Activated Protein Kinase } 8 \\
\text { Interacting Protein } 2 \\
\text { (JNK interacting protein 2) }\end{array}$ & $\begin{array}{l}\text { Receptor signaling complex scaffold } \\
\text { activity }\end{array}$ & Cell communication ; Signal transduction \\
\hline MCF2L & Guanine nucleotide exchange factor DBS & $\begin{array}{l}\text { Guanyl-nucleotide exchange factor } \\
\text { activity }\end{array}$ & Cell communication ; Signal transduction \\
\hline MVD & Mevalonate pyrophosphate decarboxylase & Carboxy-lyase activity & Metabolism ; Energy pathways \\
\hline PAX8 & Paired Box 8 & Transcription regulator activity & $\begin{array}{l}\text { Regulation of nucleobase, nucleoside, nucleotide } \\
\text { and nucleic acid metabolism }\end{array}$ \\
\hline $\begin{array}{l}\text { PGF } \\
\text { (PLGF) }\end{array}$ & Placental growth factor & Growth factor activity & Cell communication ; Signal transduction \\
\hline $\begin{array}{l}\text { PLXDC1 } \\
\text { (TEM7) }\end{array}$ & $\begin{array}{l}\text { Plexin Domain Containing } 1 \\
\text { (Tumor endothelial marker 7) }\end{array}$ & Tumor endothelial marker 7 & Cell communication ; Signal transduction \\
\hline $\begin{array}{l}\text { PTK2 } \\
\text { (FAK) }\end{array}$ & $\begin{array}{l}\text { Protein Tyrosine Kinase } 2 \\
\text { (Focal Adhesion Kinase) }\end{array}$ & Protein-tyrosine kinase activity & Cell communication ; Signal transduction \\
\hline RAC2 & Ras related C 3 botulinum toxin substrate 2 & GTPase activity & Cell communication ; Signal transduction \\
\hline RBM4 & RNA binding motif protein 4 & RNA binding & $\begin{array}{l}\text { Regulation of nucleobase, nucleoside, nucleotide } \\
\text { and nucleic acid metabolism }\end{array}$ \\
\hline REG1A & Regenerating Family Member 1 Alpha & $\begin{array}{l}\text { Extracellular matrix structural } \\
\text { constituent }\end{array}$ & Cell growth and/or maintenance \\
\hline RGS20 & Regulator of $\mathrm{G}$ protein signaling 20 & GTPase activator activity & Cell communication ; Signal transduction \\
\hline RGS7 & Regulator of $\mathrm{G}$ protein signaling 7 & GTPase activator activity & Cell communication ; Signal transduction \\
\hline RHOG & Ras Homolog Family Member G & GTPase activity & Cell communication ; Signal transduction \\
\hline RIC8B & $\begin{array}{l}\text { RIC8 Guanine Nucleotide Exchange } \\
\text { Factor B } \\
\text { (Brain synembryn) }\end{array}$ & $\begin{array}{l}\text { Guanyl-nucleotide exchange factor } \\
\text { activity }\end{array}$ & Cell communication ; Signal transduction \\
\hline RRAS & Ras related protein & GTPase activity & Cell communication ; Signal transduction \\
\hline SFTPB & Surfactant protein B & Molecular function unknown & Cellular defense response \\
\hline SLC2A4 & Solute carrier family 2 member 4 & Transporter activity & Transport \\
\hline SYDE1 & $\begin{array}{l}\text { Synapse defective } 1 \text {, Rho GTPase, } \\
\text { homolog } 1\end{array}$ & GTPase activator activity & Cell communication \\
\hline TFAP2B & Transcription factor AP-2 beta & Transcription factor activity & $\begin{array}{l}\text { Regulation of nucleobase, nucleoside, nucleotide } \\
\text { and nucleic acid metabolism }\end{array}$ \\
\hline
\end{tabular}


bioRxiv preprint doi: https://doi.org/10.1101/2021.01.23.427819; this version posted January 24, 2021. The copyright holder for this preprint (which was not certified by peer review) is the author/funder. All rights reserved. No reuse allowed without permission.

\begin{tabular}{|c|c|c|c|} 
THY1 & Thy-1 Cell Surface Antigen & Molecular function unknown & Immune response \\
\hline TNFRSF12A & TNF Receptor Superfamily Member 12A & Receptor activity & Cell communication ; Signal transduction \\
(TWEAKR) & (TWEAK receptor) & Protein threonine/tyrosine kinase & Cell communication ; Signal transduction \\
\hline TRIB1 & Tribbles homolog 1 & activity & \\
\hline
\end{tabular}

